\title{
ORDEN CONSTITUCIONAL Y GRAVES VIOLACIONES DE DERECHOS HUMANOS
}

\author{
POR \\ LUIS JIMENA QUESADA \\ Profesor Titular de Derecho Constitucional \\ Universitat de València
}

\section{EL DERECHO CONSTITUCIONAL ANTE LAS GRAVES VIOLACIONES DE LOS DERECHOS HUMANOS}

\section{Delimitación del objeto de estudio: un gran reto para nuestra disciplina}

El presente trabajo tiene como vocación y eje de análisis la optimización de la defensa de los derechos fundamentales en el ordenamiento constitucional español a la luz de la escena mundial. A tal efecto, se parte —en el plano teórico o científico- del carácter transversal y, por ende, multidisciplinar, de los derechos humanos, con especial atención a las cuestiones constitucionales que se suscitan al afrontar la responsabilidad por graves acciones atentatorias contra la dignidad humana: desde esta perspectiva, se pretende profundizar en el alcance del núcleo axiológico de la Constitución española de 1978, la dignidad de la persona reconocida en el artículo $10.1^{1}$. Esas acciones, sin lugar a dudas, comportan un peligro

${ }^{1}$ Obligada referencia doctrinal sobre esta disposición constitucional es la obra de ALEGRE MARTínez, M. A.: La dignidad de la persona como fundamento del Ordenamiento constitucional español, León, Universidad de León, 1996; así como una síntesis de dicha monografía por el mismo autor publicada bajo el título «El artículo 10.1 de la Constitución como deber genérico de respetar la dignidad y los derechos de la persona», Revista General de Derecho, n. ${ }^{\circ} 604-605,1995$. Más re- 
para la consolidación de la democracia constitucional en cualquier país y, al mismo tiempo, constituyen un factor de inestabilidad democrática internacional: $y$, desde este punto de vista, se persigue igualmente en esta investigación avanzar en la apertura internacional a que conmina el artículo 10.2 de nuestra Carta Magna².

En efecto, la escena política y económica mundial de finales del siglo XX y comienzos del siglo XXI ha conllevado una superación del ya clásico debate acerca de la obvia consideración transfronteriza de los derechos humanos en conexión con la tensión dialéctica entre la soberanía estatal y la posible injerencia o intervención en los asuntos internos ${ }^{3}$, con la controvertida irrupción de nociones más recientes como la de "acción o guerra preventiva» tras los terribles atentados del 11-S4. Se avanza así, en un terreno que se abrió paso tras la Segunda Guerra Mundial con el fin de conjurar el riesgo de un nuevo ultraje para la humanidad,

cientemente, Alegre Martínez, M. A.: «El reconocimiento constitucional de la dignidad humana: significado y alcance», en el Libro homenaje a Don Iñigo Cavero Lataillade (coord. por José Peña González), Valencia, Tirant lo Blanch/Universidad San Pablo CEU, 2005.

2 De manera exhaustiva sobre esta cuestión, el libro de SÁIZ ARNÁIZ, A.: La apertura constitucional al Derecho internacional y europeo de los derechos humanos. El artículo 10.2 de la Constitución española, Madrid, Consejo General del Poder Judicial, 1999. Para la conexión entre los apartados 1 y 2 del artículo 10 de la Constitución española, esto es, el binomio dignidad-internacionalización, acúdase a la obra de CARRILlO SALCEDO, J. A.: Dignidad frente a barbarie. La Declaración Universal de Derechos Humanos, Madrid, Trotta, 1999.

3 Las claves del principio de no injerencia en los asuntos internos, como ha recordado J. M. SÁnCHEZ PATrón (Crónica del Derecho internacional, Valencia, Repro-Expres, 2006, p. 65), ya fueron despejadas por el Tribunal Internacional de Justicia en su sentencia de 1986, recaída en el asunto Nicaragua contra Estados Unidos, en donde «identificó cuáles eran las condiciones que debían reunirse para determinar que el principio de no intervención había sido conculcado en un caso concreto. Así, la jurisdicción internacional señaló dos condiciones: la primera, requería que se afectase un asunto interno del país intervenido y, la segunda, exigía que la interferencia estuviese acompañada de un cierto grado de compulsión». Como es sabido, la Carta de Naciones Unidas de 1945 prevé el uso de la fuerza por la ONU en caso de legítima defensa como medio clásico (artículo 51 de la Carta); sin embargo, se han producido una serie de mutaciones. En este sentido, Bettati, M.: «L'usage de la force par l'ONU», Pouvoirs, n. 109 (monográfico sobre "L'ONU»), 2004, pp. 113: el autor critica la evolución «de la simple interposición a la imposición de la paz», reconociendo que «a pesar de estas mutaciones, numerosos conflictos armados escapan todavía a las acciones de las Naciones Unidas. Especialmente, el de Chechenia. De la misma manera, ni la intervención americana de 2001 en Afganistán ni la de 2003 en Irak pueden ser consideradas como decididas o autorizadas por las Naciones Unidas». Para la distinción desde el punto de vista técnico militar de esa «imposición de la paz» con respecto a las misiones de paz tradicionales, léase Alía PlanA, M.: «La imposición de la paz», http://www.derechomilitar.info/artidoc/impopaz.PDF, especialmente pp. 5-8.

${ }^{4}$ Una crítica a esa doctrina en Pérez GonZÁlez, M.: «La legítima defensa puesta en su sitio: críticas sobre la doctrina Bush de la acción preventiva», Revista Española de Derecho Internacional, n. ${ }^{\circ}$ 1, 2003, vol. LV. En el mismo sentido, con anterioridad e introduciendo una valoración crítica 
y que vio nacer el Derecho internacional de los derechos humanos como disciplina que consideraba al individuo sujeto activo, capaz incluso, más allá de la eventual protección diplomática y consular (la cual ha conocido igualmente una evolución $)^{5}$, de poner en entredicho a su propio Estado ${ }^{6}$. Se producía, de este modo, un avance asimismo respecto a la aportación complementaria del Derecho internacional humanitario.

Ahora bien, la intensificación de las relaciones internacionales y la mayor concienciación de la opinión pública mundial con relación a las graves viola-

del más amplio concepto de "autodefensa», léase GRAY, C.: «The US National Security Strategy and the New "Bush Doctrine" on Preventive Self-defense», Chinese Journal in International Law, 2002 (citado por el anterior).

${ }_{5}$ Especialmente con su reconocimiento, a escala de la Unión Europea, en el núcleo de los derechos asociados a la ciudadanía a través del Tratado de Maastricht de 1992. En el sistema interamericano, merece la pena leer la Opinión Consultiva n. ${ }^{\circ} 16$ de 1 de octubre de 1999 de la Corte de San José de Costa Rica, relativa al derecho a la información sobre la asistencia consular en el marco de las garantías del debido proceso legal, sobre la que se ha convenido en afirmar que ha inspirado la jurisprudencia internacional in statu nascendi en la materia.

${ }^{6}$ Sobre esta evolución, con especial referencia al Tribunal Europeo de Derechos Humanos, véase JIMENA QUESADA, L., y SALVIOLI, F. O.: «The individual, human rights and international instruments: focus on the Council of Europe», The ELSA Law Review, DJOF Publishing Copenhagen Denmark, Number 2, 1994. En el ámbito de la OEA, es interesante la lectura de la Opinión Consultiva OC 14/94 de la Corte Interamericana de Derechos Humanos, de 9 de diciembre de 1994 (Responsabilidad internacional por expedición y aplicación de leyes violatorias de la Convención Americana sobre Derechos Humanos), con motivo de la cual, pese a ponerse en entredicho indirectamente a los responsables de las masacres, la Corte de San José de Costa Rica concluía que la responsabilidad internacional por la violación de los derechos humanos establecidos en la Convención Americana es, en realidad, objetiva, pero «empezó a esbozar unas líneas de pensamiento sobre la responsabilidad individual remarcando, no obstante, que esencialmente su competencia está dada respecto de Estados y no de individuos»: así lo expresa SALVIOLI, F. O.: «El sistema interamericano de protección de los derechos humanos», Cours fondamentaux/Fundamental Courses, Strasbourg, Instituto Internacional de Derechos Humanos, julio 2006, p. 137. Por otro lado, una cuestión que se suscitó con motivo de las negociaciones del Estatuto de la Corte Penal Internacional pero que, finalmente, fue aparcada, tiene que ver con la legitimación pasiva de las personas jurídicas, es decir, su responsabilidad por crímenes contra la humanidad, en conexión con violaciones masivas de derechos económicos, sociales y culturales (por ejemplo, privación de acceso a alimentación y medicamentos) por grandes multinacionales, etc. En el ámbito español, la legitimación pasiva de las personas jurídicas en el orden penal se afronta en el Proyecto de Ley Orgánica por la que se modifica la Ley Orgánica 10/1995, de 23 de noviembre, del Código Penal [presentado el 20 de diciembre de 2006 y calificado el 9 de enero de 2007): BOCG (Congreso de los Diputados), VIII Legislatura, Serie A: Proyectos de Ley, 15 de enero de 2007, Núm. 119-1]: la regulación penal de las personas jurídicas — según la Exposición de Motivos— «encierra importantes dificultades generadas, como fácilmente se comprende, por el que hasta ahora pareciera infranqueable principio societas delinquere non potest). 
ciones de los derechos humanos, han forjado nuevos avances jurídicos frente a las necesidades emergentes ${ }^{7}$. Así las cosas, la evolución en materia de defensa de los derechos humanos (con nuevos derechos o nuevas garantías) ha ido acompañada del nacimiento de otras disciplinas más recientes como el Derecho internacional penal que, por cierto, se ha nutrido a su vez de una experiencia normativa interna asimismo avanzada (Derecho penal internacional, Derecho militar internacional, Derecho procesal internacional, o - en lo que nos afecta directamente- Derecho constitucional internacional ${ }^{8}$, como más sobresalientes). De esa experiencia, y por lo que se refiere a la aportación española, baste traer a colación por el momento la actuación y primeros pronunciamientos de justicia universal de algunos órganos jurisdiccionales españoles (de la Audiencia Nacional, del Tribunal Supremo y del Tribunal Constitucional, infra) como verdadero desafío para el progreso de los órganos jurisdiccionales internacionales competentes.

En todo caso, la experiencia normativa nacional debe verse como complementaria de la internacional y viceversa, pues la fuente interna y la supranacional se retroalimentan en aras de la optimización del sistema global de derechos humanos, lo mismo que se retroalimentan el juez nacional y el juez internacional en una deseable acción de sinergia. Así pues, deben entenderse superadas posturas dualistas de antaño entre Derecho interno y Derecho internacional y, con ello, una perjudicial dicotomía entre Derecho penal internacional y Derecho internacional penal; o una visión unidireccional de la posición de los tratados internacionales en el ordenamiento constitucional de cada país sin reparar correlativamente en la internacionalización de la función constituyente ${ }^{9} \mathrm{o}$ en el lugar

7 Con respecto a las «nuevas amenazas» que, en realidad, por desgracia ya se hicieron realidad durante la segunda guerra mundial, se sigue poniendo el énfasis en la necesidad de resaltar el lugar del individuo como sujeto del Derecho internacional Así, CANÇADO TRINDADE, A. A.: «The Right to Live: The Illegality Under Contemporary International Law of All Weapons of Mass Destruction", Revista del Instituto Interamericano de Derechos Humanos, n. ${ }^{\circ}$ 39, 2004, p. 69.

${ }^{8}$ Cfr. Bidart Campos, G.: El Derecho constitucional humanitario, Buenos Aires, Sociedad Anónima Editora, Comercial, Industrial y Financiera, 1996, pp. 22-23.

9 FLAUSS, J. F.: «L'internationalisation de l'exercice de la fonction constituante: une nouvelle forme de constitutionnalisme?», en el colectivo Essays in honour of Georgios I. Kassimatis, Bruxelles, Ant. N. Sakkoulas/Berliner Wissenschafts/Bruylant, 2004. Reconduzco la cuestión, por tanto y en coherencia con el objeto de esta investigación, al ámbito de los derechos humanos, sin entrar ahora en otros fenómenos más amplios (a los que tampoco resulta extraño el estudio de los derechos fundamentales) como la denominada «constitucionalización» de Europa (DíEZ-PICAZO, L. M.: «La constitucionalización de Europa", Claves de Razón Práctica, n. ${ }^{\circ}$ 64, 1996), o el uso más o menos impropio o combinado del término "constitución" para referirse al Tratado por el que se establece una Constitución para Europa (DIEZ-PICAZO, L. M.: "¿Qué diferencia hay entre un tratado y una constitución?», Cuadernos de Derecho Público, n. ${ }^{\circ}$ 13, 2001). 
de la propia Constitución en los instrumentos internacionales ${ }^{10}$. Con estos planteamientos, es mi opinión que la reflexión acerca de los mecanismos de exigencia de responsabilidad por esas graves violaciones se perfila como uno de los retos actuales más importantes del Derecho Constitucional.

Si el Derecho internacional de los derechos humanos significó una novedad tras la Segunda Guerra Mundial por realzar la posición del individuo como víctima y, consiguientemente, reconociéndole legitimación activa a escala internacional en materia de graves violaciones de derechos humanos, ese reconocimiento se ha revelado parcial, ante la necesidad de conseguir condenas, no frente al Estado como responsable internacional, sino frente a los verdaderos verdugos (personas físicas). Desde este punto de vista, y para propiciar un mayor avance en términos de seguridad jurídica y de legalidad internacionales respecto a las experiencias de los Tribunales de Nüremberg y de Tokio en el mismo contexto del segundo conflicto bélico mundial, se imponía dar cobertura normativa internacional a la legitimación pasiva en materia de graves atentados contra la dignidad humana, a lo que respondió esa rama especial del Derecho internacional de los derechos humanos que es el Derecho internacional penal.

Paralelamente, si el orden constitucional de cada Estado se ha ido abriendo a los tratados sobre derechos humanos, esa apertura se debe manifestar igualmente con relación a los específicos tratados o normas internacionales relativas a infracciones penales. En otras palabras, la evolución de la realidad y de las normas internacionales debe traducirse inexorablemente en una recepción por parte del Derecho constitucional. Por mor de la mencionada internacionalización del Derecho constitucional o, correlativamente, constitucionalización del Derecho internacional ${ }^{11}$, las relaciones entre el Derecho constitucional y el Derecho penal (y el Derecho procesal penal) se intensifican igualmente: recuérdese, de paso, que el

${ }^{10}$ Léase Jimena QUESADA, L.: «El lugar de la Constitución en los instrumentos internacionales sobre derechos humanos", en la obra colectiva Os Rumbos do Direito Internacional dos Direitos Humanos/Ensaios em homenagem ao Professor Antônio Augusto Cançado Trindade (Liber amicorum Cançado Trindade), coord. por R. Zerbini Ribeiro Leão, São Paulo, Sergio Antonio Fabris Editor, vol. 6, 2005.

${ }^{11}$ Así lo entiende EsCOBAR RocA, G.: Introducción a la teoría jurídica de los derechos humanos, Madrid, Trama editorial, 2005, p. 145: «desde el ámbito de los Estados es todavía mucho lo que queda por hacer para reforzar la vinculación de los textos internacionales, todo ello en la línea de la necesaria constitucionalización del Derecho internacional: por ejemplo, abriendo vías de apertura del catálogo de los derechos fundamentales hacia los derechos humanos, fomentando una interpretación integrada de los derechos fundamentales, tendente a las determinaciones del contenido propias de las formulaciones internacionales generosas, estableciendo mecanismos internos de ejecución de las resoluciones internacionales o abriendo vías de control judicial de los delitos contra la humanidad, cometidos fuera de las fronteras del propio Estado». 
Código penal suele tildarse de «Constitución negativa». Si los dos ejes clásicos y en tensión sobre los que pivota el Derecho penal y el proceso penal radican, de un lado, en su eficacia para salvaguardar la seguridad y los bienes jurídicos más preciados de la persona como potencial víctima y, de otro lado, en su adecuación a los cánones constitucionales de respeto de la libertad y demás derechos y garantías de los procesados, la asunción de exigencias internacionales de carácter penal impone esa intensificación o reformulación del binomio constitucionalpenal.

Con semejante planteamiento, parece obvio que la proyección de la Corte Penal Internacional o de las resoluciones de órganos judiciales españoles sobre justicia penal universal no debe recaer en exclusiva en internacionalistas, penalistas o procesalistas, como el examen del funcionamiento de la Unión Europea tampoco queda reservado a administrativistas o a internacionalistas. En ambos casos, los constitucionalistas podemos y debemos concurrir con aportaciones positivas: más aún, en ambos casos nos hallamos verdaderamente ante sendos retos del Derecho constitucional, sin necesidad de esperar a que aparezca un documento conocido como "Constitución europea», en el primer caso; o a que se pronuncie el Consejo de Estado español acerca de la compatibilidad del Estatuto de Roma de 1998 con la Constitución española, o el Tribunal Constitucional sobre la competencia extraterritorial de nuestros órganos jurisdiccionales, en el segundo caso. Es cierto que referirse al Tratado por el que se establece una Constitución para Europa de 29 de octubre de 2004 como "Constitución europea» supuso una cierta operación de "marketing constitucional» ${ }^{12}$, o que la intervención del Consejo de Estado y, sobre todo, del Tribunal Constitucional, han contribuido a dar más «visibilidad constitucional» o a una mayor constitucionalización de los dos ámbitos reseñados.

En consecuencia, debe quedar sentado que tanto las claves de la Unión Europea como de la justicia penal internacional son dos grandes retos del Derecho constitucional. Lo que sucede es que el fenómeno de la integración europea ha sido aprehendido con antelación e, incluso, con una cierta explosión de entusiasmo con ocasión del proceso de elaboración del Tratado constitucional de

12 Término que hemos utilizado Alegre Martínez, M. A., y Jimena Quesada, L.: «La Carta de los Derechos Fundamentales de la Unión Europea tras su integración en el Tratado constitucional: asimetrías, inconsistencias y paradojas», en VV.AA., Colóquio Ibérico: Constituçao Europeia. Homenagem ao Doutor Francisco Lucas Pires. Boletim da Faculdade de Direito. Studia Iuridica 84, Ad Honorem-2, Colloquia-14, Universidade de Coimbra, Coimbra Editora, 2005. Un encuadre previo, en HÄBERLE, P.: «Programas sobre Europa en Constituciones y proyectos constitucionales recientes. El desarrollo del "Derecho Constitucional nacional sobre Europa" ", en Retos actuales del Estado Constitucional, IVAP, Oñati, 1996. 
2004 (sepultado tras el tortuoso y fallido proceso de aceptación en todos los Estados miembros de la Unión Europea, y rescatado mínimamente en el nuevo Tratado de Lisboa de 2007) y del previo proceso de elaboración de la Carta de Niza de 2000: ello ha abocado a un incremento exponencial de las publicaciones de Derecho constitucional sobre la Unión Europea. Ese entusiasmo constitucionalista estaba tanto más justificado cuanto que los retos de la Unión Europea (tanto los cuatro lanzados por la Declaración sobre el futuro de Europa aneja al Tratado de Niza y por la Declaración de Laeken, como algún otro no explícitamente catalogado como tal reto) respondían lógicamente a otros tanto retos del Derecho constitucional español ${ }^{13}$. La euforia europeísta en los círculos constitucionalistas parece haberse tomado un respiro, aunque el reto consistente en reformular (tras los referendos negativos en Francia y Holanda) y revitalizar la «Constitución europea» siga vigente.

Por otra parte, en lo que atañe al fenómeno de la globalización y su aprehensión en clave de mundialización del Derecho constitucional, ha habido un enfoque más bien teórico-académico acerca de la incidencia de este proceso sobre el principio democrático y del potencial peligro de «desnaturalización» de las Constituciones (con pérdida de normatividad de la Constitución y de vigencia de las cláusulas del Estado social y el despliegue de unos nuevos valores o valores clásicos remozados con el neoliberalismo). Pues bien, el caso es que, más allá de lecturas pesimistas o exageradas del fenómeno globalizador, es preciso poner el énfasis en la idoneidad de las categorías constitucionales para dar una respuesta satisfactoria a nuevas y precisas realidades.

Con tal aproximación, una de esas realidades y retos constitucionales, tan acuciante o más que el referente a la integración europea (y en todo caso, compatible con él — sobre todo, en el ámbito del llamado «tercer pilar» de la Unión Europea), radica en mejorar los mecanismos y resortes del orden constitucional español para favorecer la exigencia de responsabilidad por graves violaciones de derechos humanos en el marco del Estado internacionalmente integrado ${ }^{14}$.

13 Así lo entendimos Alegre Martínez, M. A., y Jimena Quesada, L.: Fundamentos constitucionales de la Unión Europea, Madrid, Biblioteca Nueva, 2006 (el título originario del libro era Los retos de la Unión Europea como retos del Derecho constitucional español).

14 TORRes Del Moral, A.: Estado de Derecho y democracia de partidos, Madrid, Universidad Complutense, 2. ${ }^{a}$ ed., 2004, pp. 111-112: es la expresión que utiliza en la lección 5. («El Estado internacionalmente integrado»), en donde se hace eco de desafíos nada despreciables de nuestra vida contemporánea, entre ellos, "la mundialización de los derechos humanos, del crimen organizado y del terrorismo». 


\section{Actualidad de las cuestiones constitucionales suscitadas por las graves violaciones de los derechos humanos}

Como se decía, la intervención de órganos constitucionales españoles (como el Consejo de Estado o el Tribunal Constitucional) sobre aspectos atinentes a graves violaciones de los derechos humanos, no los constitucionaliza automática y necesariamente, aunque sin duda ello contribuya a semejante constitucionalización. Pero es que, en este caso, esas intervenciones suministran indicios más que suficiente para que nos detengamos en la relevancia constitucional de las cuestiones planteadas y en la actualidad de ellas. Así, el Dictamen plenario del Consejo de Estado español, de 22 de julio de 1999, por lo pronto, permitió constatar que el artículo 93 de nuestra Constitución, aunque concebido prácticamente ad hoc para facilitar nuestra integración europea, sirve asimismo de base habilitante para transferir el ejercicio de competencias derivadas de la Constitución a otras organizaciones supranacionales en ámbitos de indudable repercusión para el derecho a la tutela judicial efectiva (efecto de cosa juzgada, régimen de responsabilidad penal de algunos altos cargos públicos, etc.); por no hablar de la previa aceptación de la jurisdicción de los Tribunales ad hoc para exYugoslavia y Ruanda, y su problemática constitucional (en términos de juez predeterminado por la ley, etc.). Por su lado, la STC 237/2005, de 26 de septiembre ofrecía una delimitación constitucional de la competencia extraterritorial o universal de los órganos judiciales nacionales en materia de graves violaciones de derechos humanos.

Por lo demás, la intervención de los dos mencionados órganos constitucionales españoles resulta tanto más interesante cuanto que otros aspectos de incidencia supranacional penal (especialmente derivados de la cooperación judicial penal en el seno de la Unión Europea) han pasado casi desapercibidos para el intérprete constitucional (verbigracia, aspectos acordados en el marco del «espacio Schengen»), o han merecido una atención constitucional retardada (como la «euroorden»).

Como complemento de lo anterior, debe advertirse que la cuestión reviste una indudable actualidad, bastando para comprobarlo una referencia al año 2006. A principios de año, en enero de 2006, y por referencia a España, tuvo gran repercusión social, política y diplomática el reconocimiento por parte de la Audiencia Nacional de su competencia para instruir la causa por graves violaciones de derechos humanos perpetradas por el régimen chino en la región del Tibet ${ }^{15}$; la apertura de la vista oral para el segundo caso de enjuiciamiento de mi-

15 El Auto de 10 de enero de 2006 de la Sección Cuarta de lo Penal de la Audiencia Nacional admitió a trámite la querella interpuesta por diversas organizaciones (entre ellas, el Comité de 
litares argentinos ante la Audiencia Nacional, posteriormente remitido por la justicia española a la justicia argentina ${ }^{16}$; o la entrega por parte de las autoridades españolas de un militar croata a la Corte Penal Internacional ${ }^{17}$.

Y a lo largo del año 2006 se han sucedido otros episodios del género en otros países, y de los que se han hecho eco asimismo los medios de comunicación social: la desprogramación en Francia por la Comédie-Française a principios de mayo de 2006 de una obra de teatro del escritor austríaco Meter Handke por «sus posiciones pro-serbias» al acudir a las exequias del ex presidente serbio Slodoban Milosevic el 28 de marzo de $2006^{18}$; el debate sobre el bloqueo a Serbia en su camino hacia la integración en la Unión Europea por no colaborar en la captura de

Apoyo al Tíbet), contra el ex presidente chino Jiang Zemin y otros seis dirigentes de este país. En el auto se afirmaba: «de la querella presentada junto con la importante documentación acompañada, se desprende no sólo que los hechos denunciados presentan caracteres de un delito de genocidio que deben ser investigados por la jurisdicción española, sino la competencia de este órgano judicial para admitir y tramitar la querella en su día denegada, atendiendo a los postulados y principios establecidos en la STC de 26 de septiembre de 2005». El 6 de junio de 2006, el Pleno de la Sala Segunda del Tribunal Supremo ordenó (por diez votos contra cinco) investigar un nuevo caso de torturas y genocidio en China, anulando la decisión previa de la Audiencia Nacional en la que ésta había rechazado la querella presentada por el movimiento Falung Gong.

16 Se trata de otro de los militares responsables de graves violaciones de los derechos humanos en la dictadura Argentina (Ricardo Cavalho), que fue extraditado a España por Méjico en 2003. Mediante Auto de 20 de diciembre de 2006, la Audiencia Nacional resolvió no continuar con el procedimiento seguido contra Cavalho al considerar que España no tenía jurisdicción en el caso, y que aquél debía ser juzgado en Argentina, donde se cometieron los crímenes, pese a que a ese país no había demandado su extradición. A continuación, el 29 de enero de 2007 la Audiencia Nacional ordenó la puesta en libertad de Cavalho por entender que la «pérdida de jurisdicción por parte del Reino de España (...) debería determinar consecuentemente la inmediata libertad del encausado ya sometido a persecución por el Juzgado Nacional en lo Criminal y Correccional Federal número 12 de Buenos Aires»; sin embargo, unas horas más tarde (el 30 de enero de 2007), la propia Audiencia Nacional española decidió encarcelarlo mientras se decidía sobre su entrega a Argentina, que le reclamaba por delitos de lesa humanidad (su puesta en libertad el día anterior se había decretado al no haber llegado a la Audiencia Nacional su expediente de extradición en los cuarenta días preceptivos). El 2 de febrero de 2007 el Consejo de Ministros acordó continuar la tramitación en vía judicial de la solicitud de extradición de Cavalho por parte de las autoridades de Argentina, a expensas de que el Tribunal Supremo español confirmara la decisión anteriormente tomada por la Audiencia Nacional y condicionada, al tratarse de una re-extradición, al consentimiento de las respectivas autoridades mexicanas, ya que el ex militar argentino se encontraba en España, como se dijo, en virtud del acuerdo alcanzado con México.

${ }_{17}$ El 8 de diciembre de 2005 fue trasladado, desde España (tras ser detenido en Tenerife) a la Haya, el ex general croata Ante Gotovina para ser conducido ante el Tribunal Penal Internacional, en donde deberá responder por diversos crímenes previstos en el Estatuto de Roma.

18 SAlinO, B.: «Elfriede Jelinek défend Hanke», diario Le Monde, jeudi 4 mai 2006, p. 29. 
un jefe de las milicias serbias acusado de genocidio en Bosnia ${ }^{19}$; la condena en Estados Unidos al único imputado por los atentados del 11 de septiembre de 2001 detenido en dicho país, o la queja de Estados Unidos respecto a decisiones de la justicia italiana en materia de terrorismo internacional ${ }^{20}$; la intensificación de los esfuerzos normativos internacionales para luchar contra la impunidad por crímenes contra la humanidad ${ }^{21}$; el ya largo conflicto palestino-israelí con episodios como el bombardeo de la oficina del primer ministro palestino Ismaël Haniyec por el ejército israelí como represalia por el secuestro el 25 de junio de 2006 de un soldado israelí por un comando palestino (que lleva a unos y a otros a invocar a su favor el Derecho internacional humanitario ${ }^{22}$; el recrudecimiento del conflicto interno en Somalia con nuevas crisis humanitarias (o con la reciente intervención militar de Etiopía en diciembre de 2006) que van acompañadas del triste sello de la globalización ${ }^{23}$; o la creación el 3 de julio de 2006 del tribunal mixto (camboyano e internacional) encargado de juzgar los crímenes contra la humanidad cometidos entre 1975 y 1979 por el régimen represor de los jemeres rojos ${ }^{24}$; todo ello sin olvidar episodios del género que cerraron el año 2006, como la muerte de Pinochet el 10 de diciembre, o la ejecución de Sadam Hussein y los atentados terroristas en la T-4 del aeropuerto de Barajas el 30 de diciembre de $2006^{25}$.

19 Puede leerse el artículo «La Ue blocca la Serbia. Doveva arrestare Mladic», diario Corriere della Sera, giovedì 4 maggio 2006, p. 12. Del mismo día, el artículo «Handke écarté pour cause d'enterrement", diario Libération, p. 6.

${ }^{20}$ En el mismo diario italiano, y en la misma fecha, en la p. 11 pueden leerse estos otros dos artículos: «Moussaoui non sarà condannato a morte. La Giuria ha deciso: ergastolo all'unico imputato per gli attacchi dell' 11 settembre», y «Dagli Usa attacco alla Forleo: "Ha ostacolato la lotta al terrorismo". (...) accusa il giudice di Milano per il rilascio di tre sospetti».

${ }^{21}$ Véase el artículo «Disparitions forcées: l'Onu met fin à l'impunité des États. Le nouveau traité international instaure un concept inédit: le "droit à la vérité" pour les proches de personnes disparues", diario Le Figaro, lundi 3 juillet 2006, p. 5.

${ }^{22}$ Una breve aproximación a ese polémico contexto en el artículo de SÁNCHEZ PATRÓN, J. M. «Hizbolá, Israel y el derecho a la legítima defensa», diario Levante-El Mercantil valenciano, 27 de junio de 2006, p. 4.

${ }^{23}$ Véase uno de los editoriales del diario El País, del lunes 15 de mayo de 2006, titulado «Ensangrentada Somalia», p. 16.

${ }^{24}$ Léase el artículo de DERON, F.: «Les trentes juges du procès des Khmers rouges prêtent serment à Phnom Penh", diario Le Monde, jeudi 4 mai 2006, p. 5: «Los acusados —entre los que no figura el jefe jemer rojo, Pol Pot, muerto en 1998 tras un ajuste de cuentas entre antiguos camaradas - serán juzgados por genocidio y crímenes contra la humanidad que causaron la muerte de casi 2 millones de camboyanos (un tercio de la población del país) en el marco de un reino de terror que devino realmente uno de los dramas emblemáticos de las violencias de Estado del siglo XX».

${ }^{25}$ En los primeros meses de 2007 tampoco han estado ausentes ejemplos relacionados con graves violaciones de derechos humanos, como la Sentencia de 26 de febrero de 2007 del Tribu- 
El último ejemplo mencionado de tribunal híbrido nacional-internacional en Camboya pone de manifiesto nuevamente la internacionalización del Derecho constitucional o la constitucionalización del Derecho internacional cuando se trata de juzgar las graves violaciones de los derechos humanos. Así, este ejemplo, cuyo modelo ha sido ensayado en otros supuestos como el de Sierra Leona ${ }^{26}$ o fue objeto de debate asimismo como posible mecanismo para juzgar a Sadam Hussein ${ }^{27}$, evoca una solución judicial controvertida que se sitúa a caballo entre los tribunales internacionales penales y la acción universal de los tribunales nacionales penales (cuya creación y funcionamiento suscitan, respectivamente, problemas de legalidad internacional — sobre todo, los tribunales internacionales ad hoc- y de legitimidad constitucional ${ }^{28}$ ).

Al hilo de estas consideraciones, el presente trabajo de investigación persigue suscitar preguntas y ofrecer críticas constructivas o respuestas al tratamiento que puede brindar el ordenamiento constitucional español respecto a los peores atentados contra la dignidad humana con trascendencia internacional. Para

nal Internacional de Justicia de La Haya sobre la posible responsabilidad de Serbia en el genocidio perpetrado en Bosnia-Herzegovina (masacre de 1995 en Srebrenica), o la Resolución del Parlamento Europeo de 14 de febrero de 2007 condenando los vuelos secretos de la CIA en Europa con destino a Guantánamo.

${ }^{26}$ Para conocer la caracterización y la tarea que está llevando a cabo el Tribunal de Sierra Leona, puede accederse a su sitio web: www.sc-sl.org/.

27 De lectura interesante resulta el artículo de SÁNCHEZ PATRÓN, J. M.: «Iraq: ¿Guerra o terrorismo?, diario Levante, viernes, 9 de enero de 2004, p. 5. Como es conocido, Sadam Hussein fue condenado a la pena capital (y ejecutado en la horca el 30 de diciembre de 2006) por un tribunal interno internacionalmente tutelado cuya composición y funcionamiento han sido fuertemente criticados desde la perspectiva del derecho a la tutela judicial efectiva, además de las críticas por la aplicación de la pena de muerte: al respecto, ha señalado SAHAGÚN, F.: «Una ejecución ilegal e inútil», diario El Mundo, domingo 31 de diciembre de 2006, p. 2: «Ni el estatuto del tribunal ni las condiciones del proceso garantizaban un juicio limpio y justo. El primer juez del caso dimitió por presiones del Gobierno y tres de los abogados de Sadam y de los otros siete acusados fueron asesinados. El proceso ha estado politizado de principio a fin y en Derecho internacional nada contamina más un juicio que la injerencia política. Con ello quedan ensombrecidos los dos elementos más positivos de este juicio: el fin definitivo de la inmunidad de los jefes de Estado y la ausencia de límites en los juicios de crímenes de guerra o contra la Humanidad».

${ }^{28}$ Como ha subrayado VAndermeersCH, D.: «Violations graves des droits de l'homme (crimes internationaux) et compétence pénale universelle», en Protection internationale des droits de l'homme et droits des victimes/International protection of human rights and victim's rights, Strasbourg, Institut International des Droits de l'Homme, juillet 2006, p. 177: «la competencia universal puede igualmente revestir un carácter facultativo o incluso voluntario, cuando la ley interna de un Estado establece una competencia que excede las competencias obligatorias previstas por las convenciones internacionales ratificadas por ese Estado. Esta situación plantea a la vez la cuestión de la legitimidad y de la oportunidad de semejante extensión de competencia». 
ello, se parte en el epígrafe II de una elaboración propia u original de la noción de grave violación de los derechos humanos, que pretende completarse en los epígrafes sucesivos por un desarrollo lógico del examen constitucional de las diversas fases de exigencia de responsabilidad por esas graves violaciones (la investigación e instrucción en el epígrafe II, el enjuiciamiento en el epígrafe III, y el castigo de los responsables y el desagravio de las víctimas en el epígrafe IV); y se pone cierre al trabajo con un epígrafe $\mathrm{V}$ que incluye un compromiso académico y personal en clave de militancia democrática que apuesta por la profundización en un orden constitucional más justo y sensible al reto universal de la lucha contra la impunidad ${ }^{29}$.

\section{TOMA DE POSTURA: TIPIFICACIÓN DE LAS GRAVES VIOLACIONES DE LOS DERECHOS HUMANOS}

La primera originalidad que pretende recoger el presente trabajo radica en adoptar una postura propia en torno a qué se entiende por graves violaciones de derechos humanos, adoptando como criterio la catalogación de éstas por referencia a su influencia en las bases y fundamentos del ordenamiento constitucional democrático y, al tiempo, a su incidencia en la comunidad internacional. Se trata asimismo de violaciones caracterizadas especialmente por atentar de la manera más horrenda contra la dignidad humana a través de ataques a los bienes más preciados de la persona (sobre todo, la vida y la integridad), siendo además vulneraciones no necesariamente masivas y no susceptibles normalmente de una reparación íntegra o un desagravio total de la víctima.

Con el enfoque propuesto, entran en la noción de graves violaciones de derechos humanos ${ }^{30}$, de un lado, las situaciones previstas por el Derecho internacional humanitario (en especial, conflictos armados con carácter internacional y los

${ }^{29}$ La impunidad se ha definido como «la inexistencia, de hecho o de derecho, de responsabilidad penal por parte de los autores de violaciones de los derechos humanos, así como de responsabilidad civil, administrativa o disciplinaria, porque escapan a toda investigación con miras a su inculpación, detención, procesamiento y, en caso de ser reconocidos culpables, condena, incluso a la indemnización del daño causado a sus víctimas»: Informe final acerca de la cuestión de la impunidad de los autores de violaciones de los derechos humanos (derechos civiles y políticos) preparado por el Sr. L. Joinet de conformidad con la resolución 1996/119 de la Subcomisión de prevención de discriminaciones y protección de las minorías (E/CN.4/Sub.2/1997/20. 26 de junio de 1997).

${ }^{30}$ Una exhaustiva perspectiva general — que me ha ofrecido un soporte fundamental para elaborar mi postura sobre la noción de violaciones graves de derechos humanos- en la obra de SÁNCHEZ PATrón, J. M.: Las Organizaciones Internacionales ante las Violaciones de los Derechos Humanos, Oviedo, Septem Ediciones, 2004. 
conflictos armados internos, diferenciados - a veces de manera compleja- de disturbios internos y tensiones internas ${ }^{31}$-que también reclaman la atención de las organizaciones internacionales y la aplicación de un mínimo de reglas humanitarias $^{32}$ ) y penal (el genocidio, los crímenes de lesa humanidad, los crimenes de guerra y la agresión) y que repelen a la conciencia universal. Y, de otro lado, los supuestos previstos por el Derecho interno penal, tanto la interiorización de las infracciones previstas por el Derecho internacional humanitario y penal (en el caso de España, «los delitos contra la comunidad internacional» tipificados en el título XXIV del Libro II — «Delitos y sus penas»— del Código penal) como los tipos penales que socavan los fundamentos del orden constitucional democrático del país afectado directamente y, como consecuencia, la paz y la estabilidad democrática del orden internacional (las infracciones penales de trascendencia universal o extraterritorial previstas en el artículo 23.4 de la Ley Orgánica del Poder Judicial y las violaciones afrontadas por el Derecho supranacional penal, sobre todo en el marco de la Unión Europa, como es el caso el terrorismo - artículo 517 del Código penal).

Siendo obvia la repercusión transnacional de las infracciones previstas por el Derecho internacional humanitario y penal, así como las que justifican el ejercicio de la competencia extraterritorial o universal de los órganos jurisdiccionales españoles, procede asimismo afirmar que los actos terroristas tienen asimismo una relevancia constitucional-internacional. Así lo ponen de manifiesto tres vertientes del terrorismo que hemos conocido en España:

A) El denominado «terrorismo de Estado» o "guerra sucia» contra el terrorismo orquestado por los «GAL» (grupos antiterroristas de liberación), que llegaron a incursionar ilegalmente en territorio francés: al respecto, cabe destacar la STS de 29 de julio de 1998, dictada en única instancia en la causa especial n. ${ }^{\circ}$ 2530/95, caso Segundo Marey; y las SSTC 65, 66, 67, 68, 69 y 70/2001, todas ellas de fecha 17 de marzo de 2001 desestimando los amparos formulados contra aquélla (de interés igualmente la STC 155/2002, de 22 de julio).

31 Para esa delimitación, cfr. Tribunal Penal Internacional para Ruanda (Sala de $1 .{ }^{\text {a }}$ instancia), sentencia dictada el 27 de enero de 2000 en el caso «Musema», as. TPIR-96-13-T, párr. 256.

32 Como ha estudiado J. M. SÁNCHEZ PATRÓN (Las organizaciones internacionales ante las violaciones de los derechos humanos, ya cit., p. 62), «el Estado afectado por una situación de disturbios internos o tensiones internas dentro de su territorio suele apelar a su domaine réservé. Sin embargo, resulta cada vez más unánime la opinión que pone de manifiesto el Comité de Altos Funcionarios de la CSCE, según la cual “(...) las cuestiones relativas a derechos humanos, libertades fundamentales, minorías nacionales, democracia y Estado de Derecho no son exclusivamente asuntos internos del Estado de que se trate (...)". La mera existencia de una norma internacional —ya sea convencional o consuetudinaria- que garantice los derechos humanos, o alguno de ellos, sitúa su hipotética violación fuera de la exclusiva jurisdicción estatal, y por consiguiente lejos de poder considerarse como una intervención "ilícita" en los asuntos internos de los Estados". 
B) Los atentados terroristas del 11 de marzo de 2004 y posteriores perpetrados en Madrid por el mismo grupo terrorista o afines a la red de delincuencia organizada Al-Qaeda (por supuesto, se incluirían en esta categoría los atentados del 11 de septiembre de 2003 en Nueva York y del 7 de julio de 2005 en Londres), lo que propició que el Parlamento Europeo declarara el 11 de marzo día europeo de las víctimas del terrorismo. La vertiente internacional de este tipo de terrorismo ha comportado que la justicia española se vea llamada a pronunciarse, no sólo sobre los atentados del 11-M (reciente sentencia de la Sala de lo Penal de la Audiencia Nacional hecha pública el 31 de octubre de 2007), sino igualmente sobre las células relacionadas con el 11-S presentes en nuestro país: así, en la sentencia de la Sala de lo Penal (Sección 3. ${ }^{\text {) }}$ de la Audiencia Nacional n. ${ }^{\circ}$ 36/2005 de 26 de Septiembre (recaída en el sumario 35/01 del Juzgado Central de Instrucción n. ${ }^{\circ}$ 5). De esa misma causa contra las células de Al Qaeda en España trae su origen otra reciente sentencia de la propia Sala de lo Penal (Sección 4. ${ }^{a}$ ) de la Audiencia Nacional n. ${ }^{\circ}$ 43/2005 de 4 de octubre (caso del "talibán español», sumario 25/03 del Juzgado Central de Instrucción n. ${ }^{\circ}$ 5); esta sentencia, no obstante, fue revocada por el Tribunal Supremo (Sala de lo Penal) mediante Sentencia n. 829 de 22 de junio de 2006 (dictada en el recurso de casación núm. 1188/2005 P), en cuyo fallo se decidió por unanimidad la absolución del recurrente «del delito de integración en banda armada del que venía siendo condenado", haciendo valer la presunción de inocencia con una fuerte crítica a la situación de Guantánamo.

En este mismo orden de cosas, desde una perspectiva constitucionalista, la lucha frente al terrorismo internacional, sobre todo a raíz de los atentados del 11-S, además de la depuración de la responsabilidad penal individual en vía judicial, ha comportado la adopción de una controvertida legislación de «autodefensa» no sólo en Estados Unidos, sino asimismo en Europa. En efecto, los atentados del 11-S en Nueva York no comportan únicamente un debate general sobre cómo afrontar desde el Derecho constitucional el desafío del «déficit de seguridad» y de las graves violaciones de los derechos humanos, sino asimismo un examen concreto de la medidas mediante las cuales los Estados pretenden hacer frente a ese desafío, es decir, del modo que en los Estados asumen responsablemente las obligaciones positivas que pesan sobre ellos. La ilustración de ello la ofrece la Sentencia del Tribunal Constitucional Federal Alemán de 15 de febrero de 2006, sobre la Ley de Seguridad Aérea, que autorizaba a derribar un avión secuestrado para cometer un atentado terrorista ${ }^{33}$. En el ámbito español, los aten-

33 En su estudio crítico sobre dicha sentencia (bajo el título «Una cuestión de principios», Revista Española de Derecho Constitucional, n. ${ }^{\circ} 77$, mayo-agosto 2006) observa J. M. RODRÍGUEZ DE SANTIAGO que «el Tribunal Constitucional Federal no se ha pronunciado sólo sobre la inconsti- 
tados del 11-M han generado igualmente un debate que ha llegado al ámbito legislativo en materia de control del comercio de armas, pudiendo citarse en esta línea el Proyecto de Ley sobre el control del comercio exterior de material de defensa $y$ de doble uso $0^{34}$.

C) Y, por supuesto, el terrorismo de ETA, sobre cuyo fin se venía especulando con gran énfasis en el pasado año 2006 tras el llamado «alto el fuego permanente» declarado por la organización terrorista y el inicio de la negociación política, hasta el terrible atentado a finales de año en el aeropuerto de Barajas ${ }^{35}$.

tucionalidad de una ley, sino también sobre la inconstitucionalidad de una actuación del Estado - la de derribar el avión secuestrado, esté o no regulada por ley: la Sentencia contiene una prohibición de esa actuación — declarada como objetivamente contraria a la Constitución— cuando en el avión viajan víctimas inocentes. Sin duda, como pusieron de manifiesto las opiniones doctrinales anteriores a la Sentencia, el Estado no puede permanecer inactivo y está llamado a actuar en casos como el planteado, en los que están en juego bienes constitucionales de primer orden. Queda por responder a la pregunta: ¿cómo?» (p. 272). Con esta aproximación, cabe mencionar las «medidas para la prevención de atentados terroristas» previstas en el capítulo 3 del Tratado de Prüm de 27 de mayo de 2005, concretamente los artículos 17 (escolta de seguridad en los vuelos) y 18 (armas de servicio, munición y equipos).

34 Proyecto de Ley presentado el 29 de diciembre de 2006 y calificado el 9 de enero de 2007 [Proyecto de Ley 121/000121, BOCG (Congreso de los Diputados), VIII Legislatura, Serie A: Proyectos de Ley, 15 de enero de 2007, Núm. 121-1]. En la Exposición de Motivos del Proyecto puede leerse: «desde la perspectiva de la seguridad nacional e internacional, se trata de impedir el tráfico ilícito y la proliferación de armamentos y tecnologías sensibles a favor de estados o actores no estatales susceptibles de actuar contra la paz y la seguridad o de involucrarse en actividades terroristas. Por otro lado, se busca responder a una significativa demanda política y social de control del comercio de material de defensa y productos y tecnologías de doble uso. Todo ello sin perjuicio de las legítimas exigencias del comercio legal de armas, elemento íntimamente vinculado a la defensa nacional y a las legítimas actividades de mantenimiento de la Ley y la lucha de los gobiernos contra el delito. Durante la tramitación parlamentaria de ese proyecto legislativo se están sucediendo algunas críticas sociales: al respecto, en el artículo de I. M. GARCía titulado «El G-8 no cumple» (diario $A D N$, jueves 10 de mayo de 2007, p. 13) se critica que - recogiendo impresiones de algunas ONGs como Intermón Oxfam o Amnistía Internacional se trata de «una ley de armas poco transparente», pues «no asegura la cadena de venta ni impide que se exporten a países en conflicto o que no protegen los derechos humanos».

35 ETA declaró el «alto el fuego permanente» el 24 de marzo de 2006, rompiéndolo de forma gravísima el 30 de diciembre de 2006 con el terrible atentado en la terminal T-4 del Aeropuerto de Barajas en Madrid, con dos víctimas mortales, algunos heridos, daños materiales de enorme envergadura y, sobre todo, sentimiento de confusión y desesperanza sobre el final de la violencia terrorista. Esa confusión vino alimentada por el comunicado de la banda terrorista ETA (publicado en el diario Gara, del martes 9 de enero de 2007) reivindicando el atentado y, al tiempo, sosteniendo que el alto el fuego continuaba vigente. El Gobierno de Rodríguez Zapatero inicialmente declaró «suspendido» el diálogo con ETA tras dicho atentado, pues con dicha acción terrorista no se cumplirían las condiciones de la Resolución aprobada por el Congreso de los Dipu- 
Pese a ello, la especulación al respecto continúa ${ }^{36}$. Como se decía, no merece el calificativo de conflicto armado interno ni, por supuesto, internacional, ni tampoco el de disturbio interno o tensión interna, semejante consideración no ha sido incompatible, dada su proyección internacional, con su tratamiento en los foros supranacionales. Así, en la Unión Europea, en el plano político la Eurocámara incluyó a Batasuna y grupos afines (considerados brazos políticos del terrorismo etarra) en una lista de partidos políticos que sustentan el terrorismo ${ }^{37}$,

tados el 17 de mayo de 2005 [por 192 votos a favor (PSOE, CiU, ERC, PNV, IU-ICV, CC y grupo Mixto -BNG, CHA, EA y NB) y 147 en contra (PP)] en la que se da soporte al «final dialogado" de ETA en condiciones estrictas de ausencia de violencia, declarándose que "convencidos como estamos de que la política puede y debe contribuir al fin de la violencia, reafirmamos que, si se producen las condiciones adecuadas para un final dialogado de la violencia, fundamentadas en una clara voluntad para poner fin a la misma y en actitudes inequívocas que puedan conducir a esa convicción, apoyamos procesos de diálogo entre los poderes competentes del Estado y quienes decidan abandonar la violencia, respetando en todo momento el principio democrático irrenunciable de que las cuestiones políticas deben resolverse únicamente a través de los representantes legítimos de la voluntad popular. La violencia no tiene precio político y la democracia española nunca aceptará el chantaje (...) Expresamos nuestra solidaridad con las Víctimas del Terrorismo. (...) Seguiremos apoyando al conjunto de las Fuerzas y Cuerpos de Seguridad del Estado: Guardia Civil, Policía Nacional y la Ertzaintza. (...) Expresamos nuestra convicción de que la colaboración internacional, particularmente en el seno de la Unión Europea, entre los Gobiernos y los distintos poderes judiciales es indispensable para la erradicación de la violencia, a fin de prevenir la comisión de nuevos atentados y evitar la impunidad de quienes los cometen».

36 Así, por ejemplo, ese debate se avivó a cuenta de unas declaraciones del Rey Don Juan Carlos efectuadas el 9 de mayo de 2007 en una charla informal con periodistas (y de la que luego se hicieron eco todos los medios de comunicación y que fue objeto de mayor o menor politización según los diversos partidos) con motivo de una visita a la sede de la Dirección General de la Guardia Civil, en donde destacó la importancia del nuevo Gobierno de unidad formado en Irlanda del Norte el 8 de mayo de 2007 entre protestantes y católicos, añadiendo que esos logros hay que intentarlos y matizando que el caso irlandés es diferente al español.

37 En paralelo a las dificultades de definición del terrorismo han aflorado problemas de conceptuación de organización o grupo terrorista: así, en la Unión Europea, partiendo del concepto previo de "organización criminal» establecido en la Acción Común del Consejo de 21 de diciembre de 1998, se incluyó inicialmente un concepto de "grupo terrorista», en la Posición Común del Consejo 2001/931/PESC, de 27 de diciembre de 2001 sobre la aplicación de medidas específicas de lucha contra el terrorismo, pasando a ser retomado en la Decisión marco 2002/475/JAI, concretamente en su artículo 2 (Delitos relativos a un grupo terrorista): «organización estructurada de más de dos personas, establecida durante cierto período de tiempo, que actúa de manera concertada con el fin de cometer delitos de terrorismo». Así, la Posición Común 2001/931/PESC se acompanó de un anexo con un listado de personas, grupos y entidades, en donde se incluían los irlandeses, un par de grupos islámicos (Hamas Yihad islámica palestina), así como ETA y las entidades de su entorno (KAS, Ekin, Kaki, Jarrai-Haika-Segi y Gestoras Pro-amnistía —originariamente no se habían incluido Herri Batasuna ni Euskal Herritarrok). En este mismo contexto, debe mencio- 
mientras que en el terreno normativo (entre otros motivos, a causa de ese mismo terrorismo y a instancia de España) se adoptó el controvertido Convenio de 27 de septiembre de 1996 establecido sobre la base del entonces artículo K.3 del Tratado de la Unión Europea relativo a la extradición entre los Estados miembros, y la más prometedora - aunque tampoco exenta de controversia- Decisión marco adoptada el 13 de junio de 2002 por el Consejo de Ministros de Justicia e Interior de la Unión Europea relativa a la orden de detención europea y a los procedimientos de entrega entre Estados miembros (conocida como «euroorden»).

Por su parte, el Consejo de Europa tampoco ha permanecido ajeno al tratamiento del problema del terrorismo como violación grave de los derechos humanos, con la elaboración de recientes tratados en la materia: en lo que concierne a los mecanismos jurisdiccionales, el Tribunal Europeo de Derechos Humanos seguramente se habrá de pronunciar sobre la ilegalización en España de Batasuna y partidos afines (Ley Orgánica 6/2002, de 27 de junio, de Partidos Políticos), después de haber inadmitido ratione personae la primera demanda presentada por el Gobierno vasco frente a España (demanda n. ${ }^{\circ}$ 29134/2003) mediante Decisión de fecha 3 de febrero de 2004.

$\mathrm{Al}$ margen de lo anterior, la cuestión de la lista de organizaciones que financian el terrorismo establecida en la Unión Europea, que ha sido objeto de pronunciamientos ante la Justicia comunitaria [cabe citar dos sentencias de fecha 21 de septiembre de 2005 del Tribunal de Primera Instancia de la Unión Europea (asunto T-306/01 y asunto T-315/2001), que rechazan los recursos de los afectados por las medidas restrictivas adoptadas contra personas y entidades asociadas a la red terrorista de Bin Laden, Al Qaeda y los talibanes, con apoyo en la PESC] ${ }^{38}$, se planteó igualmente ante el Tribunal Europeo de Derechos Humanos (particularmente, en el caso Segi y otros contra Austria, Bélgica, Dinamarca, Finlandia, Francia, Alemania, Grecia, Irlanda, Italia, Luxemburgo, Paises Bajos, Por-

narse la Sentencia del Tribunal Supremo (Sala de lo Penal) de 19 de enero de 2007 (recurso de casación n. ${ }^{\circ}$ 1/1841/2005), en donde se declara que Jarrai, Haika y Segi, grupo juveniles de la izquierda abertzale, son organizaciones terroristas y no meras asociaciones ilícitas, revocando con ello la sentencia previa de la Audiencia Nacional.

38 En el fondo se suscitan problemas bajo el ángulo de los derechos de defensa: BARTOLONI, M. E.: «La tutela giurisdizionale nell'ambito del secondo e terzo pilastro UE», Quaderni costituzionali, n. ${ }^{\circ}$ 1/2005, PP. 170-174: con alusión al auto del Tribunal de Primera de Instancia de 7 de junio de 2004 (causa T-338/02, Segi y otros) se analizan en este trabajo de manera crítica los defectos de tutela jurisdiccional con respecto a un acto adoptado en el ámbito de la PESC (posición común 01/931/PESC — publicada en el DOUE L 344/93-) relativo a la aplicación de medidas específicas para la lucha contra el terrorismo, que fue adoptado sobre la base de los artículos 15 y 34 TUE para hacer recepción de la Resolución del Consejo de Seguridad de Naciones Unidas 1373 (2001) relativa a la lucha contra el terrorismo. 
tugal, España, Suecia y Reino Unido de 23 de mayo de 2002). En el contexto de las garantías no jurisdiccionales, es preciso mencionar el informe del Comisario para los Derechos Humanos del Consejo de Europa acerca de la situación en el País Vasco sobre la visita efectuada a dicha Comunidad Autónoma del 5 al 8 de febrero de 2001.

La tipificación de las graves violaciones de derechos humanos debe ser completada delimitando las infracciones reseñadas: por una parte, desde la perspectiva sustancial, de otros tipos de acciones que atentan contra la vida y la integridad, pero que no tienen su origen en la violencia (por ejemplo, en materia de seguridad e higiene en el trabajo), pese a tener un tratamiento colectivo, como las que se sustancian a través las reclamaciones colectivas ante el Comité Europeo de Derechos Sociales (Reclamación n. ${ }^{\circ}$ 10/2000 (Tehy ry y STTK ry contra Finlandia, decisión de fondo de 17 de octubre de 2001). Y, por otra parte, desde el punto de vista procedimental, de otras violaciones masivas que, pese a su carácter violento, no dan lugar a la exigencia de responsabilidad penal individual subjetiva de los infractores, sino a la puesta en marcha de otros mecanismos más insatisfactorios de responsabilidad internacional objetiva del Estado (por ejemplo, el mecanismo de demandas interestatales ante el Tribunal Europeo de Derechos Humanos - caso Irlanda contra Reino Unido de 18 de enero de 1978, y en el caso Chipre contra Turquía de 10 de mayo de $2001-{ }^{39}$ o ante la Corte Interamericana de Derechos Humanos — ningún caso, aunque interesante la Opinión Consultiva OC-14/94, de 9 de diciembre de 1994, Responsabilidad internacional por expedición y aplicación de leyes violatorias de la Convención Americana sobre Derechos Humanos), que no comportan una reparación equitativa o integral para las víctimas ${ }^{40}$. Todo ello in olvidar otros remedios igualmente insatisfactorios, por su

39 Léase REIDY, A.: «The approach of the European Commission and Court of Human Rights to International Humanitarian Law», International Review of the Red Cross, n. ${ }^{\circ} 324,1998$, así como FLAUSS, J. F.: "Le droit international humanitaire devant les instances de contrôle des Conventions européenne et américaine des droits de l'homme», en el colectivo Les nouvelles frontières du droit international humanitaire (dir. por J.F. Flauss), Bruxelles, Bruylant/Nemesis, 2003, en particular, el epígrafe «La réticence de la Commission et de la Cour européennes à se référer au droit international humanitaire», p. 121.

$40 \mathrm{Al}$ abordar «la prueba del daño moral» apostando por «la no tan difícil difficilioris probatio», han destacado Alegre Martínez, M. A. y Mago Bendahán, O.: Derechos de la personalidad y Derecho de los daños morales, Caracas, Editorial Constitución Activa (Breviarios del Nuevo Derecho), 2007, p. 173: «consideramos conveniente incluir el aspecto de la participación en la justicia, ya que la víctima, quien es poseedora del gran secreto del daño que se le causó, debe tener participación en el diseño de la solución que más le conviene. Obsérvese que decimos participación y no un simple derecho de petición o acceso a la justicia. Igualmente los expertos deberían tener un peso vinculante para elaborar el criterio de la veracidad. La posibilidad de sentencias sin pruebas se manifiesta en la 
potencial grado de politización (por ejemplo, el mecanismo previsto en el artículo 7 del Tratado de la Unión Europea para riesgo de atentado grave por un Estado miembro contra los derechos o valores comunes): el primer caso planteado con apoyo en esta disposición europea (el supuesto monopolio ejercido de hecho por el ex Primer Ministro italiano Berlusconi en materia de medios de comunicación), ha concluido por el momento con una resolución del Parlamento Europeo de abril de 2004 en la que se denuncia esa situación recomendando un cambio de legislación a Italia y se aprovecha para reprochar a otros países prácticas contrarias a la libertad de información (verbigracia, se denuncia respecto de España la presunta manipulación informativa en los medios públicos con motivo de los atentados del 11-M en Madrid) ${ }^{41}$.

\section{CONSIDERACIONES CONSTITUCIONALES SOBRE LA INVESTIGACIÓN E INSTRUCCIÓN DE LAS GRAVES VIOLACIONES DE LOS DERECHOS HUMANOS}

\section{Marco constitucional español y medidas adoptadas a escala europea}

Una vez conceptuadas las graves violaciones de los derechos humanos, debe analizarse la cuestión referente a su persecución, empezando por el tratamiento constitucional en España de su investigación e instrucción. En este terreno, cabe subrayar cómo las medidas previstas por el marco constitucional español para la investigación policial y judicial de causas graves relativas a derechos humanos (por ejemplo, la suspensión individual de determinados derechos prevista en

legislación y en la jurisprudencia (...). Ello, a nuestro modo de ver, constituye una mala praxis en el enjuiciamiento, con lo que la víctima puede resultar condenada a sufrir un mal peor». Con carácter previo, ambos autores se ocupan del «pretium doloris» para lo cual, ante la inexistencia de un «dolorímetro», apuntan diez elementos a valorar en la apreciación del daño moral: 1) Proporción del daño-afectación real de la víctima-necesidad de la víctima-resarcimiento. 2) La situación social, política y económica de las personas involucradas. 3) Las condiciones en que ocurrió la ofensa o el perjuicio moral, la intensidad del sufrimiento o humillación. 4) El grado de dolo o de culpa y la existencia de la retractación espontánea (por parte del ofensor) o el esfuerzo de minimizar la ofensa o lesión. 5) Si ha habido por parte de la víctima el perdón tácito o expreso. 6) La cultura de la persona, la cual incluiría sus valores familiares y sociales y su gado de sensibilidad. 7) La duración del agravio en el tiempo (si ha sido instantáneo, si ha sido continuado). 8) La publicidad que ha tenido el caso y la opinión pública. 9) La participación de la víctima en la causación del daño. 10) Los factores de posible exoneración de la responsabilidad del causante.

${ }^{41}$ Resolución del Parlamento Europeo sobre el peligro que corre en la UE, y particularmente en Italia, la libertad de expresión y de información (DOCE C 104 E de 30/04/2004). 
el artículo 55.2 de la Constitución española para bandas armadas y elementos terroristas, y desarrollada mediante la Ley de enjuiciamiento criminal — piénsese en la prórroga por dos dias del periodo ordinario de detención preventiva, o la incomunicación de los detenidos en dependencias policiales durante el plazo de la detención, con limitación del derecho a designar letrado — avalada por STC 7/2004 de 9 de febrero), se han visto completadas por otras medidas adoptadas por los órganos competentes españoles haciendo recepción de las recientes tendencias internacionales (por ejemplo, auto dictado el 13 de diciembre de 2006 por el Juzgado Central de Instrucción n. 5 de la Audiencia Nacional en el que se ordenaba grabar en vídeo el período de incomunicación de los detenidos por terrorismo, siguiendo las recomendaciones efectuadas en marzo de 2006 por el relator especial de la ONU sobre la tortura), o por medidas policiales y judiciales acordadas en el seno de la Unión Europea en el marco del «tercer pilar» y del «acervo de Schengen» (por ejemplo, y sobre todo, la euroorden).

En particular, los acuerdos alcanzados en el ámbito de la Unión Europea tienden a reducir el déficit de seguridad con medidas compensatorias muy importantes para luchar contra quienes perpetren graves violaciones de derechos humanos: así, desde las más contundentes como la persecución policial transfronteriza en el caso de flagrante delito — «en caliente»— o en el marco de una investigación judicial ${ }^{42}$, hasta las más recientes como los equipos conjuntos de investigación $^{43}$, pasando por el uso de los medios de comunicación modernos verbigracia, el Sistema de Información de Schengen, SIS; véase, mutatis mutandis, Auto del Tribunal Constitucional n. ${ }^{\circ}$ 2/1992, de 13 de enero, sobre validez de informe remitido por INTERPOL- Correlativamente, esas medidas compensatorias han planteado problemas en torno a las garantías para la libertad y los derechos procesales de los infractores ${ }^{44}$, así como en lo relativo al encuadre constitucional de esas medidas desde el punto de vista del déficit democrático y de las fases ascendente y descendente de ejecución del Derecho de la Unión:

${ }^{42}$ Una visión exhaustiva de las medidas adoptadas al efecto en dicho marco en MORENO CAtena, V., y Castillejo Manzanares, R.: La persecución de los delitos en el Convenio de Schengen, Valencia, Tirant lo Blanch, 1999.

43 Véase Choclán Montalvo, J. A.: «Delincuencia transfronteriza y equipos conjuntos de investigación", en Cuadernos de Derecho Judicial (monográfico sobre Derecho penal supranacional y cooperación jurídica internacional), Madrid, Consejo General del Poder Judicial, 2003.

${ }_{44}$ En este contexto, se ha insistido en que «el peligro del forum shopping no es del todo imaginario. ¿Cómo actuar respecto al intercambio de informaciones obtenidas de manera ilícita? ¿Qué garantías se adoptan para que la información sea controlable?», VAN OUTRIVE, L.: «Schengen, Europol y la colaboración policial internacional: un desafío para la democracia», Cuadernos de la Guardia Civil, n. ${ }^{\circ} 4$ (monográfico sobre La seguridad interior en la Unión Europea), 1995, p. 188. 
puede traerse a colación la tensión entre el Ejecutivo y el Consejo General del Poder Judicial en materia de nombramiento de los miembros españoles en esas unidades policiales o judiciales europeas, de magistrados de enlace, etc. (cfr. Ley 11/2003, de 21 de mayo, reguladora de los equipos conjuntos de investigación penal en el ámbito de la Unión Europea, y Ley 16/2006, de 26 de mayo, por la que se regula el Estatuto del Miembro Nacional de Eurojust y las relaciones con este órgano de la Unión Europea).

Por lo demás, pese a instrumentos avanzados importantes como el SIS (y Europol), todavía se siguen produciendo avances tecnológicos que facilitan la investigación de graves violaciones de derechos humanos y que, sin embargo, merecen una regulación específica para evitar problemas de insuficiencia normativa que comporte una limitación desproporcionada en los derechos fundamentales de las personas que sean objeto de una investigación criminal: a tal desafío responde, por ejemplo, la Ley Orgánica 10/2007, de 8 de octubre, reguladora de la base de datos policial sobre identificadores obtenidos a partir del ADN, que se hace eco de medidas propuestas tanto desde el Consejo de Europa [Recomendación (92) 1, de 10 de febrero de 1992, del Comité de Ministros, sobre utilización de los resultados de análisis de ADN en el marco del sistema de justicia penal] como desde la Unión Europea (por ejemplo, el Consejo de la Unión a través de sendas Resoluciones relativas al intercambio de resultados de análisis de ADN, de 9 de junio de 1997 y de 25 de julio de 2001), sin olvidar nuestra jurisprudencia constitucional a la hora de abordar la protección de los derechos fundamentales en la obtención de pruebas a partir de los perfiles de ADN (por ejemplo, STC 207/1996, de 16 de diciembre), o la adecuación a la Ley Orgánica 15/1999.

Con carácter adicional, no debe perderse de vista la posible colaboración militar, una participación armada que adquirió fuerza en la Unión Europea por influencia de Estados Unidos tras los atentados del 11-S, pese a los enfoques diversos en Europa (policial) y en Norteamérica (militar) en materia de terrorismo ${ }^{45}$. De hecho, llegó a incluirse en el Tratado por el que se establece una

45 De forma crítica ha distinguido ambos enfoques FERnÁNDEZ TOMÁs, A. F.: «Constitución Europea y terrorismo», ya cit., pp. 137-139: «Tras los acontecimientos del 11 de septiembre de 2001, la Unión Europea adoptó un primer Plan de Acción antiterrorista. El objetivo era entonces ayudar a los norteamericanos a resolver los problemas causados por el terrorismo islámico y a prevenir su reiteración. (...) El Consejo Europeo de 25 y 26 de marzo de 2004 adopta una Declaración contra el Terrorismo, dentro de la cual se forma una Estrategia Europea de Seguridad (EES) que incluye el Plan de Acción Revisado de la Unión Europea. (...) Con todo, se intenta componer un modelo europeo de respuesta que cobre autonomía respecto del rechazable modelo de "guerra contra el terror" preconizado por el Gobierno Bush (...). El modelo nortemaricano, concibe el terrorismo como un problema de defensa, y aplica para su "solución" fórmulas militares. La ac- 
Constitución para Europa de 29 de octubre de 2004 la denominada «cláusula de solidaridad» en el artículo I-43. A pesar de no haber llegado a alcanzar vigencia la «Constitución europea», España se ha hecho eco de la potencial puesta en práctica de dicha cláusula, adecuando a tal efecto esos nuevos cometidos de las fuerzas armadas españolas en el ámbito internacional a través de la Ley Orgánica 5/2005, de 17 de noviembre, de la Defensa Nacional (artículos 2 y 15.3).

\section{Asistencia penal internacional e instrumentos novedosos: particular atención a la "euroorden»}

En lo que atañe más estrictamente a la construcción del Espacio Judicial Europeo, es indudable que de todos los mecanismos de asistencia penal internacional (comisiones rogatorias, traslado de personas condenadas, ejecución de sentencias extranjeras), en materia de persecución de graves violaciones de derechos humanos ha cobrado un interés especial en la Unión Europea y en los ordenamientos constitucionales de los Estados miembros la figura clásica de la extradición y la novedosa «euroorden» [aprobada mediante Decisión-Marco de 13 de junio de 2002 (2002/584/JAI), e incorporada a España mediante Ley Orgánica 3/2003 de 14 de marzo, habiendo tenido su primera aplicación con el Auto de 10 de febrero de 2004 de la Sala Penal de la Audiencia Nacional]. Con la «euroorden» se pretende superar las disfunciones provocadas (sobre todo, en materia de terrorismo) por la figura clásica de la extradición en el marco de la Unión Europea, de las que merecen destacarse dos: una de ellas, relativa a la armonización de los tipos delictivos ${ }^{46}$, tiene que ver con el rechazo de demanda extradicional por el país requerido en un entendimiento rígido y formalista del principio de doble incriminación, al no considerarse equivalentes las figuras de colaboración o pertenencia a banda armada, banda terrorista, banda de malhechores o asociación mafiosa ${ }^{47}$. La otra, estrechamente vinculada a la anterior, consiste en la poca

tuación de las coaliciones lideradas por los EEUU en Afganistán e Irak pone de manifiesto las pautas de ese modelo que no respeta ni la Carta de las Naciones Unidas, ni el trato que el Derecho internacional humanitario exige para los combatientes y prisioneros de guerra. (...) Por el contrario, el modelo europeo concibe la respuesta al terrorismo como un problema de seguridad interion.

${ }^{46}$ Véase FAUCHON, P.: Vers la construction d’un espace judiciaire européen?, Les rapports du Sénat, n. ${ }^{\circ} 352$, Paris, 1996-1997, pp. 19-20: el autor destaca el handicap constituido por la ausencia de unificación de los tipos y los procedimientos penales en el caso de la lucha contra la criminalidad organizada y el terrorismo, poniendo ejemplos de divergencias entre países (por ejemplo, entre el Código penal italiano y el Código penal francés).

47 En efecto, es importante subrayar que la entrega de la persona reclamada por medio de la euroorden, a diferencia de lo establecido en el artículo 6 de nuestra Ley de Extradición Pasiva (se- 
exitosa adopción del también mencionado Convenio de 27 de septiembre de 1996 relativo a la extradición entre los Estados miembros de la Unión Europea, en el cual, uno de sus puntos controvertidos era la exclusión total de la figura del asilo político entre esos Estados, como causa para la denegación de una extradición salvo en caso de que en el país requirente se hubiera recurrido a la adopción de medidas excepcionales de suspensión de derechos con apoyo en el artículo 15 del Convenio Europeo de Derechos Humanos.

Lo bien cierto es que, en Europa, esa «euroorden» se sitúa en un tercer estadio, en la medida en que: por un lado, se supera el llamado «sistema de lista» introducido por los Tratados internacionales de extradición clásicos, mediante los que regía entre los Estados Partes la obligación recíproca de entregarse a los delincuentes por la comisión de alguno de los delitos del elenco establecido en el Tratado; como fácilmente se colegirá, la imperfección técnica del sistema derivaba de dejar impunes los delitos que no figuraran en el listado. Por otro lado, se mejora asimismo el segundo mecanismo, más avanzado, instituido mediante el Convenio Europeo de Extradición del Consejo de Europa de 13 de diciembre de 1957, que sustituyó el sistema de lista por el de «mínimo punitivo», de modo que procedía la entrega extradicional cuando el delito que daba lugar a la petición de entrega estuviera castigado en el Estado requirente y en el requerido (principio de doble incriminación) con la pena mínima señalada en el Convenio (principio de mínimo punitivo). Además, con la «euroorden» se simplifican enormemente los trámites procedimentales, estableciéndose un plazo máximo de entrega (sesenta días, prorrogables por otros treinta excepcionalmente), y se

gún la cual la resolución del Tribunal declarando procedente la extradición no es vinculante para el Gobierno), se producirá dentro de los diez días siguientes a la decisión judicial de entrega, sin más trámites, y sin necesidad de control de la doble tipificación de los hechos cuando se trate de alguno de los delitos que en catálogo cerrado se enumeran (así lo ha subrayado PUERTA LUIS, L.R.: "Derecho penal supranacional y cooperación jurídica internacional», ya cit., p. 35). Véase asimismo MARIN, L.: "Il ne bis in idem dello spazio penale europeo», Quaderni costituzionali, n. ${ }^{\circ}$ 3/2005, pp. 681: la autora se refiere a los riesgos de la supresión del principio de doble incriminación en la orden europea de detención, «fenómeno que merece atención, por cuanto en la legislación penal encuentra su fundamento y límite la máxima expresión del poder coactivo del Estado sobre el individuo, es decir, el uso de la fuerza y la restricción de la libertad individual». La cuestión todavía es más compleja cuando se confronta con sistemas diversos, por ejemplo, con Estados Unidos: véase PASQUERO, A.: "Il mutuo riconoscimento delle decisioni penali nel mandato d'arresto europeo e nella rendition statunitense», Rivista di diritto internazionale privato e processuale, n. ${ }^{\circ}$ 4, 2005, pp. 978-979: el trabajo plantea los problemas que se derivarían de la aceptación de la «euroorden» en Estados Unidos bajo la óptica del principio de la doble incriminación, con apoyo en el principio del «full faith and credit» sentado en la jurisprudencia de la Supreme Court norteamericana. 
diseña un formulario susceptible de ser cumplimentado fácilmente por la autoridad judicial que pide la entrega. Pero, sobre todo, el otro punto que me parece esencial a los efectos de instrucción de causas frente a presuntos responsables de graves violaciones de los derechos humanos, radica en que el procedimiento se despolitiza, esto es, que se prescinde de la intervención de la autoridad política dándose pie a que la persecución internacional de los delitos se lleve a término directamente entre órganos judiciales (el gobierno de cada país intervendría, en su caso y exclusivamente, para prestar apoyo técnico, consistente en la traducción de la orden de entrega al idioma del país requerido $)^{48}$.

Aun con todo, el funcionamiento de la «euroorden» no deja de plantear problemas desde el punto de vista del respeto de los derechos constitucionales de defensa, habiendo sido ya objeto de análisis crítico por parte de la jurisdicción constitucional española. En comparación con la postura adoptada por otras jurisdicciones constitucionales extranjeras, me ha parecido más acertado el enfoque efectuado por el Tribunal Constitucional español (STC 339/2005, de 20 de diciembre), consistente en no haber suscitado un problema genérico de utilización de este procedimiento especialmente acelerado de extradición (de "turboextradición» se ha hablado en ocasiones), sino en sancionar las concretas disfunciones susceptibles de merecer un otorgamiento del amparo constitucional en supuestos específicos ${ }^{49}$. Al contrario, en Alemania, el Tribunal Constitucional federal alemán, mediante sentencia de 18 de julio de 2005, declaró la nulidad de la Ley alemana de 21 de julio de 2004 que incorporaba la euroorden por cuanto, en esencia, dicha ley no preveía la negativa a entregar a la persona reclamada

$48 \mathrm{Al}$ respecto, DE Miguel Zaragoza, J.: «Algunas consideraciones sobre la Decisión Marco relativa a la orden de detención europea y a los procedimientos de entrega en la perspectiva de la extradición", Actualidad Penal, n. ${ }^{\circ} 4$ (semana del 20 al 26 de enero de 2003): según el citado autor, la "euroorden» consistiría en una extradición simplificada, sin que se altere esa naturaleza jurídica extradicional por el hecho de que se elimine la intervención de los Ministerios de Justicia y se acentúe el protagonismo de los sistemas judiciales.

49 Suscribo así el balance efectuado por Arangüena Fanego, C.: «La Orden Europea de Detención y Entrega. Análisis de las Leyes 2 y 3 de 14 de marzo de 2003, de transposición al ordenamiento jurídico español de la decisión marco sobre la euroorden", Revista de Derecho Penal, n. ${ }^{\circ}$ 10, 2003: si bien la autora concluye que la transposición ha sido aceptable en líneas generales y realizada con prontitud (p. 94), critica que «sin embargo, y quizás por esa rapidez, su resultado final no es satisfactorio, abriéndose numerosos interrogantes en cuanto a su tramitación, al haberse limitado prácticamente a llevar al texto de la ley las líneas contenidas en la Decisión marco sin haberse preocupado de efectuar el debido ajuste en atención a las exigencias y principios que informan nuestro modelo procesal penal, encomendando el procedimiento a dos órganos jurisdiccionales diversos sin un claro y adecuado reparto de competencias entre ambos, y negando la posibilidad de recurrir la decisión de entrega» (p. 95). 
cuando el delito se hubiera cometido en Alemania ni permitía interponer un recurso contra la decisión de entrega.

Desde luego, asumiendo semejante crítica (la sentencia trae su origen del recurso de amparo promovido por un ciudadano sirio nacionalizado alemán que, a través de una euroorden, fue reclamado por España para ser enjuiciado en nuestro país como presunto integrante de Al Qaeda), la posición de la jurisdicción constitucional alemana se fundamenta en un criticable juicio abstracto ${ }^{50}$, y adicionalmente plantea un problema de responsabilidad supranacional europea y ralentiza la cooperación judicial en el seno de la Unión, por cuanto los jueces de los demás países europeos que se dirijan a las autoridades judiciales germanas no tendrán más remedio que seguir acudiendo a la extradición clásica ${ }^{51}$.

${ }^{50}$ Comparto así la crítica formulada por TomUSCHAT, Ch.: «Inconsistencias: la sentencia del Tribunal Constitucional alemán de 18 de julio de 2005 sobre la orden europea de detención y entrega», Teoría y Realidad Constitucional, n. ${ }^{\circ}$ 18, 2006, pp. 256 y 263: en esa sentencia «se aprecia que el Tribunal ha estructurado sus explicaciones conforme al modelo del control abstracto de normas, sin ocuparse en detalle del caso concreto o de las implicaciones para el recurrente. En ningún lugar se examina la especial afectación a los derechos fundamentales del recurrente; la supuesta lesión es deducida simplemente del hecho de que la Ley sobre asistencia jurídica internacional en materia penal, en la redacción que le da la Ley sobre la orden europea de detención, no satisface las exigencias generales en materia de derechos fundamentales que derivan de los arts. 16.2, frase segunda [la libertad de los ciudadanos alemanes frente a la extradición a un tercer Estado], y 19.4 GG, y por ello también de los arts. 2.1 y 20.3 GG. (...) El Tribunal dedica una atención extraordinaria al reproche de la "desestatalización". (...) Menos fácil de ver es la razón por la que en este contexto se rechaza, de forma un tanto admonitoria, una "armonización general del Derecho penal de los Estados miembros”. ¿Por qué una liga de Estados (Staatenverbund), que se ve a sí misma como una comunidad política con valores comunes, no puede proponerse una armonización del Derecho penal, que ha de ser concebido justamente como instrumento para proteger tales valores comunes?». Con similar sentido crítico, que comparto, al comentar esa sentencia constitucional alemana sobre la «euroorden», ha advertido VIDAL PRADO, C.: Revista Española de Derecho Constitucional, n. ${ }^{\circ} 77$, mayo-agosto 2006, p. 274: «El Tribunal se ha detenido más en subrayar la primacía del Derecho constitucional alemán sobre el Derecho comunitario, que en entrar, por ejemplo, a estudiar las implicaciones concretas del caso que tenía entre manos, relacionado con el terrorismo internacional. Tampoco parecen haberle preocupado al BVerfG las consecuencias que su decisión puede tener de cara al proceso de integración europea. Es más, algunas de las afirmaciones no permiten albergar expectativas demasiado favorables hacia este proceso, aunque siempre puede haber una rectificación, incluso parcial, de las posiciones que se contienen en la sentencia».

${ }^{51}$ Más crítico con la postura de la jurisdicción constitucional española se ha mostrado DE LA QUADRA-SALCEDO JANINI; T.: «El encaje constitucional del nuevo sistema europeo de detención y entrega (reflexiones tras la STC 177/2006, de 5 de junio)", Revista Española de Derecho Constitucional, n. ${ }^{\circ} 78,2006$ : "Al contrario de lo que ha ocurrido en otros países en los que los Tribunales Constitucionales se han planteado la constitucionalidad de determinados aspectos contenidos en las leyes nacionales de transposición de tal decisión marco, en nuestro país el Alto Tribunal ha preferido "sortear" tales cuestiones", lo que dicho autor reconduce — al comentar la STC 177/2006_ 
Por último, en el marco de la reseñada discusión constitucional, es preciso mencionar la reciente sentencia del Tribunal de Justicia de la Unión Europea (Gran Sala) de 3 de mayo de 2007 (asunto C-303/05, caso Advocaten voor de Wereld VZW y Leden van de Ministerraad), mediante la que se pronuncia directamente sobre la Decisión marco 2002/584/JAI relativa a la euroorden, con motivo de una cuestión prejudicial planteada, con arreglo al artículo 35 del Tratado de la Unión Europea, por el Arbitragehof belga. La cuestión prejudicial trae su petición presentada en el marco de un recurso interpuesto por la asociación Advocaten voor de Wereld VZW ante el Arbitragehof con el fin de que se anulara la Ley belga de 19 de diciembre de 2003, relativa a la orden de detención europea. El fallo del Tribunal de Justicia apuesta por no poner reparos al proceso de integración europea, declarando textualmente que «el examen de las cuestiones planteadas no ha revelado ningún elemento que pueda afectar a la validez de la Decisión marco 2002/584/JAI del Consejo, de 13 de junio de 2002, relativa a la orden de detención europea y a los procedimientos de entrega entre Estados miembros»; y ello tras analizar la Decisión marco sobre la base del principio de legalidad de los delitos y las penas y del principio de igualdad y no discriminación.

\section{La instrucción desde España de violaciones de derechos humanos de trascendencia universal}

Expuesto lo anterior, seguramente la cuestión de mayor relevancia para el ordenamiento constitucional en materia de instrucción de causas violaciones graves de derechos humanos ha sido la operada desde España por crímenes cometidos en otros países. Y, en esta línea, la jurisprudencia constitucional española ha establecido un criterio amplísimo para el ejercicio de la competencia extraterritorial o universal por parte de los órganos judiciales españoles al interpretar el alcance del artículo 23.4 de la Ley Orgánica del Poder Judicial (STC 237/2005, de 26 de septiembre, sobre genocidio del pueblo maya en Guatemala).

Con semejante disposición legal, si es cierto que pueden generarse conflictos de jurisdicción, en contrapartida se da respuesta al problema de la validez espacial de la ley penal o, mejor aún, se superan los escollos que, para la instrucción desde España de violaciones graves de derechos humanos perpetradas en otros

a la falta de motivación suficiente acerca de la exigencia de reciprocidad y a la falta de condicionamiento de la entrega a la exigencia de revisión de la sentencia condenatoria dictada en ausencia del condenado. 
países, podría plantear el criterio clásico de la territorialidad. Pues, en efecto, este principio de territorialidad o principio de forum loci comissi constituye el criterio principal de atribución de jurisdicción, de modo que con el recurso a la competencia universal o extraterritorial se sortean los problemas y las teorías relativas a qué debe entenderse por lugar de comisión del delito, pues en teoría las normas que reconocen validez extraterritorial a la norma penal siempre colisionarán con el criterio de atribución de jurisdicción por el lugar del hecho.

En cualquier caso, el criterio sentado en la STC 237/2005 fue precedido por asuntos de gran repercusión en los medios de comunicación como la petición de extradición del ex dictador Pinochet al Reino Unido por parte del Juzgado de Instrucción n. ${ }^{\circ} 5$ de la Audiencia Nacional e, incluso antes, por ese mismo Juzgado, la primera manifestación de esa justicia universal desde España (Auto de 28 de junio de 1996 respecto de cientos de ciudadanos españoles o familiares de españoles durante la dictadura militar argentina entre 1976 y 1983). A continuación se profundiza en esta justicia universal ejercida desde España. Si acaso, conviene recordar nuevamente que una lamentable ironía del destino ha determinado que el ex dictador chileno falleciera en 2006 el Día internacional de los derechos humanos (10 de diciembre), lo que ha conducido a archivar todas sus causas penales pendientes sin poder ser condenado por los crímenes cometidos ${ }^{52}$.

52 Ello sin perjuicio de las causas colaterales que afectan a familiares y allegados de Pinochet, por la enorme fortuna que acumuló éste en cuentas secretas en el exterior. A su muerte, el ex dictador chileno estaba procesado por fraude tributario, malversación de caudales públicos y utilización de pasaportes falsos. En realidad, las causas pendientes se redujeron considerablemente tras la Resolución de 3 de enero de 2007 de la Sala Quinta de la Corte de Apelaciones de Santiago de Chi$l e$, que dejó sin efecto la mayor parte de los procesamientos dictados en enero de 2006 por el juez Carlos Cerda - dotando de firmeza en cambio a los procesamientos de un ex albacea como cómplice de evasión tributaria, y de uno de sus hijos como autor de declaraciones tributarias maliciosamente incompletas - (en octubre de 2006 había trascendido que Pinochet habría ocultado nueve mil kilos de oro en lingotes valorados en ciento veintisiete millones de euros, en un banco de Hong Kong; en contrapartida, en febrero de 2005 se había producido algún avance, como la aceptación por un banco de Estados Unidos - Banco Riggs National Corp, con sede en Washington, D.C.- de pagar ocho millones de dólares a un fondo de resarcimiento a las víctimas de crímenes cometidos por el ex dictador chileno y antiguo cliente de la entidad financiera, a cambio de que se retiraran los cargos penales y civiles contra la compañía y siete ex y actuales directores y empleados). Con respecto a este último supuesto mencionado, se pone de manifiesto no sólo el ejercicio «clásico» de justicia universal en el ámbito penal (ese acuerdo tuvo su impulso fundamental en la acción de la Audiencia Nacional española contra Augusto Pinochet), sino asimismo la acción extraterritorial judicial en el terreno civil: sobre esta cuestión, puede leerse FLAUSS, J. F.: "Violations graves des droits de l'homme et compétence civile universelle», en Protection internationale des droits de l'homme et droits des victimes/International protection of human rights and victim's rights, Strasbourg, Institut International des Droits de l'Homme, juillet 2006. 


\section{PERFILES CONSTITUCIONALES DEL ENJUICIAMIENTO DE LAS GRAVES VIOLACIONES DE LOS DERECHOS HUMANOS}

\section{La apertura del orden constitucional a la jurisdicción penal internacional}

Analizadas las claves de la investigación e instrucción en o desde España de graves violaciones de derechos humanos, el siguiente paso consiste en examinar la fase de enjuiciamiento por esos graves atentados. En este campo se abordan dos niveles: en el primero, las previsiones de la normativa interna respecto a la entrada en escena del Derecho internacional penal y humanitario y de los órganos supranacionales competentes. Y, en el segundo nivel, la regulación interna que otorga competencia universal a los órganos jurisdiccionales nacionales para enjuiciar esas causas graves en materia de derechos humanos. Teniendo en cuenta, en tercer lugar, la necesaria acción de sinergia, cooperación y complementariedad entre ambos niveles.

Pues bien, la aproximación al primer nivel nos lleva, especialmente, a reflexionar sobre los problemas de constitucionalidad suscitados en el ordenamiento español por la ratificación del Estatuto de la Corte Penal Internacional (Ley Orgánica 6/2000, de 4 de octubre). En particular, de las diversas cuestiones de relevancia constitucional, me parece interesante partir de aquella que ponía en entredicho el estatuto especial del Jefe del Estado español y de nuestros representantes parlamentarios y gubernamentales, lo que en mi opinión fue correctamente salvado con la utilización de la base habilitante del artículo 93 de la Constitución española, de suerte que esas cláusulas constitucionales [las referentes a la irresponsabilidad del Monarca (artículo 56.3), así como a la inmunidad y el fuero especial ante la Sala Penal del Tribunal Supremo de los parlamentarios (artículo 71) y de los miembros del Gobierno (artículo 102)] serían compatibles con la exigencia de responsabilidad ante la Corte Penal Internacional [artículo 25 del Estatuto de Roma (responsabilidad penal individual), en conexión con los artículos 27 (improcedencia de cargo oficial) y 28 (responsabilidad de los jefes y otros superiores) del propio Estatuto]. Una solución similar a la española (innecesaria reforma constitucional para asumir el Estatuto de Roma) se siguió en otros países miembros de la Unión Europea, como Austria, Holanda o Italia.

Sin embargo, una solución diversa respecto a dicha problemática se alcanzó en otros países: de interés resulta la lectura de la sentencia del Tribunal Constitucional chileno de 9 de abril de 2002, en donde se declaró que el Estatuto de Roma contradecía los preceptos de la Constitución Política de Chile en materia de inviolabilidad y fuero parlamentario, de prerrogativas reconocidas a los jueces 
chilenos, de autoridad para otorgar los beneficios del indulto y la amnistía (como atribuciones especiales del Presidente de la República o del Parlamento, respectivamente), o de incompatibilidad de las funciones de la Fiscalía ante al Corte Penal Internacional con las funciones atribuidas constitucionalmente a los fiscales chilenos. El Alto Tribunal chileno subrayó para llegar a tal conclusión que la Constitución chilena no contiene una cláusula de apertura supranacional (semejante al artículo 93 de la Constitución española, por ejemplo) que dote de flexibilidad a la interpretación del edificio constitucional, por lo que fue preciso acometer la reforma de la Ley Fundamental ${ }^{53}$. A similar solución de reforma constitucional se llegó en otros países de la Unión Europea como Francia (Decisión No 98-408 DC del Consejo Constitucional, de 22 de enero de 1999, y Ley Constitucional $N^{\circ}$ 99-568, de 8 de julio de 1999), Luxemburgo (Dictamen del Consejo de Estado de 4 de mayo de 1999 y Ley de 8 de agosto de 2000), República de Irlanda (Vigésima Tercera Enmienda de la Constitución, que entró en vigor el 27 de marzo de 2002) o Portugal (Ley Constitucional de 12 de diciembre de $2001)^{54}$.

Retornando a nuestras fronteras, la cuestión expuesta no era baladí en el caso de España, por las consecuencias que hubieran podido derivarse de su participación en la guerra de Irak o en otras misiones futuras en las que participen fuerzas militares españolas. Así, es menester destacar un primer pronunciamiento de la jurisdicción española que, no obstante haber declarado inadmisible el asunto, puede tener interés para casos posteriores que eventualmente se sustancien en España o ante la Corte Penal Internacional: el Auto de la Sala Penal del Tribunal Supremo (Sala segunda) de 21 de enero de 2004 (causa especial n. ${ }^{\circ}$ 142/2003 y acumuladas), que acuerda inadmitir las querellas formuladas por varios miles de ciudadanos contra el ex Presidente del Gobierno y otros aforados (Ministros de exteriores y de defensa), denunciando la participación de España en la guerra de Irak sin la previa autorización de las Cortes Generales prevenida en el artículo 63.3 de la Constitución (artículo 588 del Código Penal vigente de 1995), así

53 En la doctrina chilena, BERTELSEN, R.: «Rango Jurídico de los Tratados Internacionales en el Derecho Chileno», Revista Chilena de Derecho, Vol. 23, n. ${ }^{\circ} 2$ y 3, Tomo I, p. 219: “¿Cabe, entonces, alguna duda que las normas de los tratados internacionales sobre derechos humanos están subordinadas a la Constitución si pueden ser contrastadas con los preceptos de ésta para ser declaradas inaplicables? Nada se innovó en 1989, por consiguiente, en la solución tradicional chilena sobre la superioridad de las normas constitucionales sobre las de los tratados internacionales».

${ }^{54}$ En algunos otros países de la Unión Europea, la incorporación del Estatuto de Roma también ha tenido relevancia constitucional, como ha ocurrido en Alemania. Al respecto, puede leerse WILKITZK, P.: "The German Law on cooperation with the ICC», Revue internationale de droit pénal (Association internationale de droit pénal), 1.\%/2. ${ }^{\circ}$ trimestres de 2005, pp. 97-103. 
como las acciones que se califican como delitos contra personas y bienes protegidos en caso de conflicto armado (artículos 608 a 616 del Código Penal).

En su resolución, el máximo órgano de la jurisdicción ordinaria española reconoce previamente su competencia "ratione personae» (artículo 102.1 de la Constitución - responsabilidad criminal del Presidente y los demás miembros del Gobierno). En cuanto al fondo del asunto, desde la perspectiva constitucionalista, tras descartar los delitos previstos en los artículos 608 a 616 del Código penal (por considerar los hechos de mero apoyo logístico o político), interesa recalcar que respecto a la incoación del procedimiento penal por los hechos que los denunciantes califican como delito del artículo 588 del Código Penal (declaración de guerra sin cumplir lo dispuesto en la Constitución), el Tribunal Supremo determina que no concurre la competencia «ratione materiae» para esa incoación, puesto que este tipo de delitos se encuadraría entre los delitos de traición (Capítulo primero del Título XXIII del Código Penal), de lo que se derivaría la consecuencia prevista en el artículo 102 de la Constitución («la acusación sólo podrá ser planteada por iniciativa de la cuarta parte de los miembros del Congreso, y con la aprobación de la mayoría absoluta del mismo" $)^{55}$.

A mi entender, la solución procedimental basada en las cláusulas constitucionales de la justicia penal como justicia política no deja de ser insatisfactoria y, desde una aproximación estrictamente jurídica, cabría suscitar si ello conculca el derecho a un proceso equitativo reconocido en el artículo 6 del Convenio de Roma de 1950 como mecanismo para pedir protección frente a supuestas graves violaciones de los derechos humanos, en la interpretación efectuada por el Tribunal Europeo de Estrasburgo en determinados asuntos: por ejemplo, el caso Cordova contra Italia $n . .^{\circ}$, de 30 de enero de 2003, en donde se considera contrario a la tutela judicial efectiva que la prerrogativa de inmunidad ex artículo 68 de la Constitución italiana degenere en un privilegio injustificado para evitar el procesamiento de un parlamentario haciendo prevalecer el criterio meramente político de la Cámara frente al de la justicia.

Por supuesto, otra cuestión diversa, en el extremo opuesto, sería el problema de respeto de la legalidad internacional referente al doble grado de jurisdicción en el caso de los aforados (Comité de Derechos Humanos en el caso Gómez Váz-

55 Pueden leerse al respecto las monografías de DíEZ-PICAZO, L.M.: La responsabilidad penal de los miembros del Gobierno, Madrid, Centro de Estudios Constitucionales, 1996; GARCía MAHAMUT, R.: La responsabilidad penal de los miembros del Gobierno en la Constitucion, Madrid, Tecnos, 2000; OBREGÓN GARCíA, A.: La responsabilidad criminal de los miembros del Gobierno: análisis del artículo 102 de la Constitución Española, Madrid, Civitas, 1996; y SeIjAS VILLADANGOS M. E.: Responsabilidad jurídica del Gobierno y defensa de la Constitución, León, Universidad de León, Secretariado de Publicaciones, 2003. 
quez contra España, de 20 de julio de 2000) ${ }^{56}$, y en general en el orden penal (Proyecto de Ley Orgánica por la que se adapta la legislación procesal a la Ley Orgánica 6/1985, de 1 de julio, del Poder Judicial, se reforma el recurso de casación y se generaliza y la doble instancia penal $)^{57}$.

Al contrario, el referido Auto de la Sala Penal del Tribunal Supremo (Sala segunda) de 21 de enero de 2004 no genera discusión en cuanto al archivo de las querellas en lo que afectaba a su extensión (ratione personae) al jefe del Gobierno británico puesto que, de un lado, cabalmente la competencia para la persecución penal de los graves hechos denunciados — en el caso hipotético de poder procederse contra el Premier británico- correspondería en España a la Audiencia Nacional; y, de otro lado, en materia de inmunidad de los jefes de Estado y miembros del Gobierno en activo, basta traer a colación la sentencia de la Corte Internacional de Justicia de la Haya, de 14 de febrero de 2002, que condenó a Bélgica por la orden de arresto internacional dictada contra el Ministro de Asuntos Exteriores en activo de la República Democrática del Congo.

\section{Delimitación constitucional de la competencia extraterritorial de los órganos jurisdiccionales españoles}

El segundo de los niveles avanzados (delimitación constitucional de la competencia extraterritorial de los órganos jurisdiccionales españoles para juz-

56 Véase De LuCCi López-TAPIA, Y.: «Nuevas consideraciones sobre el derecho al recurso penal (El dictamen del Comité de Derechos Humanos y la jurisprudencia constitucional en el caso Segundo Marey)», Revista de Derecho Procesal, n. ${ }^{\circ}$ 1-3, 2002, p. 349: la autora critica la ausencia de la doble instancia en el caso de los aforados, sobre lo que el Tribunal Constitucional se pronunció por vez primera (avalando no obstante esa ausencia) en las SSTC 64, 65 y 66/2001. Para efectuar tal crítica se apoya en la llamada de atención a España por parte del Comité de Derechos Humanos en el caso Gómez Vázquez contra España, de 20 de julio de 2000 (Comunicación n. ${ }^{\circ}$ 701/1996). Esa línea se ha seguido por el Comité en asuntos posteriores: caso J. Semey contra España de 30 de julio de 2003 (Comunicación n. ${ }^{\circ}$ 986/2001); caso M. Sineiro Fernández contra España de 7 de agosto de 2003 (Comunicación n. ${ }^{\circ}$ 1007/2001); caso J. M.a Alba Cabriada contra España de 1 de noviembre de 2004 (Comunicación n. $\left.{ }^{\circ} 1101 / 2002\right)$; y caso A. Martínez Fernández contra España de 29 de marzo de 2005 (Comunicación n. ${ }^{\circ}$ 1104/2002).

57 De esta vulneración de la legalidad internacional se tiene conciencia en España y, a tal efecto, se ha discutido en la VIII Legislatura (2004-2008) el Proyecto de Ley Orgánica por la que se adapta la legislación procesal a la Ley Orgánica 6/1985, de 1 de julio, del Poder Judicial, se reforma el recurso de casación y se generaliza y la doble instancia penal (vid. su Exposición de Motivos). Al respecto, CALDERÓN CUADRADO, P.: «La generalización — rectius, desaparición- del doble grado de jurisdicción en el proceso penal español», Revista de Derecho Procesal, 2006, en particular, pp. 633641. 
gar graves violaciones de los derechos humanos) cuenta con antecedentes internacionales (sentencia de 11 de julio de 1996 del Tribunal de Justicia de la Haya, dictada en el caso Bosnia contra República Federal de Yugoslavia) y comparados de interés (la sentencia de fecha 20 de diciembre de 1985 pronunciada por la Corte de Casación francesa en el caso Klaus Barbie; la propia sentencia de la Cámara de los Lores del Reino Unido de 24 de marzo de 1999 dictada en el caso Pinochet, o la sentencia de 12 de febrero de 2003 dictada por la Corte de Casación belga en el caso Sharon y otros). Ahora bien, la solución española (STC 237/2005, de 26 de septiembre) es más avanzada y ha marcado un antes y un después en el ordenamiento español. Con anterioridad a ese pronunciamiento, la referencia fundamental venía constituida por la sentencia n. 327 de 25 de febrero de 2003 dictada por el Tribunal Supremo en recurso de casación n. ${ }^{\circ}$ 803/2001, formulado contra Auto de la Sala Penal de la Audiencia Nacional de 13 de diciembre de 2002 que declaró la incompetencia de la jurisdicción española para pronunciarse sobre las querellas formuladas por diversas asociaciones (secundando la denuncia de la Premio Nobel de la Paz Rigoberta Menchú) sobre delitos de genocidio, torturas y terrorismo perpetrados en Guatemala entre 1978 y 1986. Y bien, esa sentencia del Tribunal Supremo de 25 de febrero de 2003 es precisamente la recurrida en amparo ante el Tribunal Constitucional, que admitió a trámite el recurso mediante providencia de 18 de mayo de 2004, resolviendo el fondo mediante la reiterada STC 237/2005, de 26 de septiembre.

Sin entrar en la polémica en torno a la "guerra de cortes» entre el Tribunal Constitucional y el Tribunal Supremo ${ }^{58}$, lo cierto es que resultaba difícil que el primero confirmara (al menos totalmente) la sentencia del segundo. En el marco de esta controversia, el Tribunal Supremo, por una ajustada mayoría de ocho votos contra siete, adoptó una postura — excesivamente comedida a mi parecer- del ejercicio de la justicia universal en España, interpretando de manera restrictiva el alcance del repetido artículo 23.4 de la Ley Orgánica del Poder Judicial: en síntesis viene a efectuarse una modulación, no prevista en el artículo 23.4 de la Ley del Poder Judicial, del alcance de la justicia extraterritorial en España, seleccionando como «elemento de conexión en el ámbito del principio de jurisdicción universal» el de la nacionalidad de las victimas y otros posibles criterios de conexión para la persecución universal de las violaciones graves a los derechos humanos (que la justicia del territorio donde se hayan cometido esas violaciones no proceda a su persecución, o que el presunto culpable se encuentre en

58 Véase SERRA CRISTÓBAL, R.: La guerra de las Cortes. La revisión en amparo de la jurisprudencia del Tribunal Supremo, Madrid, Tecnos, 1999. 
territorio español o la relevancia de un interés nacional), concluyendo que estos elementos no concurrían en el caso de autos.

Frente a ello, la STC 237/2005, de 26 de septiembre declara que el derecho a la tutela judicial efectiva, y especialmente el derecho de acceso a la jurisdicción, impide establecer semejantes criterios; en otros términos, la competencia universal de los órganos jurisdiccionales españoles competentes no queda sometida ni a la presencia de víctimas españolas ni a la existencia de esos intereses nacionales. En todo caso, sin necesidad de contar con el soporte de esta controvertida, al tiempo que benévola, jurisprudencia constitucional, la Audiencia Nacional española (Sala de lo Penal, Sección 3. ${ }^{a}$ ) pronunció sólo unos meses antes una sentencia histórica (sentencia n. ${ }^{\circ}$ 16/2005, de 19 de abril de 2005), al ser la primera que resolvía el fondo de un asunto de justicia universal. En ella se condenaba a Adolfo F. Scilingo por un delito de lesa humanidad cometido durante la dictadura argentina. Un aspecto interesante de la sentencia radica en que, en ella, los magistrados de la Audiencia Nacional estiman «que más que la exacerbación cuantitativa de la pena, lo que deben garantizar esta clase de delitos es su persecución eficaz", "a través de la internacionalización de su persecución, imprescriptibilidad, etc.».

Desde luego, la STC 237/2005, por polémica que pueda parecer en cuanto a su carácter extraterritorial prácticamente ilimitado (con la excepción de los jefes de Estados y miembros del Gobierno en activo, según la jurisprudencia de la Corte Internacional de Justicia — sentencia de 14 de febrero de 2002, sobre el arresto en Bélgica del Ministro de asuntos exteriores de la Republica Democrática del Congo - ; además — pero susceptible de fiscalización-, que el delincuente no haya sido indultado, absuelto o penado en el extranjero), me merece una valoración positiva. Por lo pronto, es preferible que se ofrezca la posibilidad de persecución universal de graves violaciones de derechos humanos aunque finalmente esa posibilidad no llegue a verificarse, antes que establecer criterios restrictivos que ni siquiera den pie para plantear semejante posibilidad, con la carga que ello comporta de pasividad frente a la impunidad. Ciertamente, podrá achacarse a la STC 237/2005 que resulta demasiado pretenciosa a priori e incluso ilusoria frente a persecución de hechos gravemente atentatorios para la dignidad con trascendencia para la comunidad internacional y que, adicionalmente, el criterio benévolo del Tribunal Constitucional podrá tener un efecto de atracción (con la consiguiente sobrecarga de trabajo de los órganos jurisdiccionales españoles) respecto de este tipo de asuntos criminales. Siendo ello así, como decía, es preferible disponer de esa posibilidad amplia de ejercicio de la competencia extraterritorial (disponibilidad) antes que carecer de ella para, en caso de imposibilidad, que 
sea eventualmente la Corte Penal Internacional quien ejerza su competencia; lo cual, dicho sea de paso, traslada el problema a la posibilidad de la propia Corte Penal ${ }^{59}$.

\section{Acción de sinergia y retroalimentación del orden constitucional $y$ del orden internacional}

A la luz de lo acabado de exponer, resulta ineludible enfocar, de manera entrecruzada, los dos niveles acabados de analizar, por referencia a la acción de sinergia y retroalimentación de ambos. En este caso, es interesante efectuar la ilustración sobre la base de dos acciones complementarias, una normativa y la otra jurisprudencial, ambas producidas en España. La primera se refiere a la Ley Orgánica 18/2003, de 10 de diciembre, de Cooperación con la Corte Penal Internacional, que encierra la misma filosofía que la anterior Ley Orgánica 15/1994, de 1 de junio, para la cooperación con el Tribunal internacional para el enjuiciamiento de los presuntos responsables de violaciones graves del derecho internacional humanitario cometidas en el territorio de la ex-Yugoslavia, o la Ley Orgánica 4/1998, de 1 de julio, para la cooperación con el Tribunal internacional para Ruanda ${ }^{60}$.

Sin duda alguna, uno de los extremos relevantes de la entrega de un presunto responsable por parte de España a la Corte Penal radica en la limitación de los motivos de denegación de la solicitud, apartándose de los modelos clásicos en materia de extradición, ya que ni siquiera la existencia de cosa juz-

59 Desde este punto de vista, ha hecho notar Olásolo, H.: «El alcance de la potestad jurisdiccional de la Corte Penal Internacional a la luz del marco procesal del Estatuto de Roma», Revista Poder Judicial, n. ${ }^{\circ}$ 78, 2005, p. 86: "la experiencia de los tribunales ad hoc, y en particular del TPIY, muestra que incluso con un presupuesto y una dotación de personal muy superiores a los de la Corte no es posible celebrar más de media docena de juicios orales al año». En cuanto a la Corte Penal Internacional, los tres primeros procedimientos abiertos lo han sido contra presuntos responsables de crímenes contra la humanidad cometidos en República Democrática del Congo (abierto el 23 de junio de 2004), en Uganda (abierto el 29 de julio de 2004) y en Sudán (abierto el 6 de junio de 2005). Este último caso fue remitido a la Corte Penal por el Consejo de Seguridad de la ONU a consecuencia de la situación en Darfur. Por supuesto, la propia Corte Penal se ve sometida a garantías procesales y sustanciales: así, por ejemplo, cuenta con un centro de detención en La Haya (recibió una primera visita del Comité Internacional de la Cruz Roja los días 28 y 29 de junio de 2006) y ya se ha visto confrontada a pronunciarse sobre hechos como huelga de hambre de detenidos.

${ }^{60}$ Como antecedente de interés de estas dos leyes, cabe mencionar el Dictamen del Consejo de Estado (Comisión Permanente) de 9 de septiembre de 1993, sobre introducción en el Derecho Interno Español de la Resolución 827 del Consejo de Seguridad de las Naciones Unidas sobre Tribunal Penal Internacional para castigo crímenes internacionales en la antigua Yugoslavia. 
gada puede impedir la entrega, sin perjuicio de la eventual valoración que efectúe luego la Corte: acercándose al espíritu de la ya estudiada «euroorden», se judicializa el sistema eliminándose las llamadas fases gubernativas, siendo competentes para la entrega los Juzgados Centrales de Instrucción de la Audiencia Nacional. Así, profundizando en esta faceta preferencial, cabría teóricamente suscitar dudas de constitucionalidad cuando la Corte Penal Internacional considere que una sentencia interna ya firme ha sido un ejercicio ficticio de la justicia y entre a corregirla o revisarla, lo que formalmente plantea contradicción con los principios constitucionales de cosa juzgada y de non bis in idem ${ }^{61}$.

El Consejo de Estado español alertó, en su Dictamen de 22 de julio de 1999, sobre la posible contradicción en esta materia entre la Constitución española y el Estatuto de Roma, llegando no obstante a la conclusión de que «la cesión de competencias judiciales a la Corte Penal Internacional (sobre la base del artículo 93 de la Constitución española) habilitaría a ésta para, en las circunstancias y por los cauces establecidos por su "ley reguladora" [refiriéndose al Estatuto de Roma] debidamente integrada en el ordenamiento español, modificar en su caso las resoluciones de los órganos españoles». Comparto esa opinión del Consejo de Estado. Por otra parte, en lo concerniente a la ejecución de las sentencias de la Corte, se reproduce la matización respecto de las penas privativas de libertad que ya figura en la Declaración efectuada por España en la Disposición Adicional única de la Ley Orgánica 6/2000 de ratificación del Estatuto de Roma, en la que, a efectos de lo previsto en el apartado b) del artículo 103.1 del Estatuto, se intenta evitar a título "preventivo» una posible colisión con los fines de reeducación y reinserción previstos en el artículo 25.2 de la Constitución española en materia de reclusión a perpetuidad ${ }^{62}$.

En lo que afecta a la aportación jurisprudencial, en la línea de la reseñada acción de sinergia entiendo interesante mencionar el primer supuesto que desde España se ha remitido a la Corte Penal Internacional, a saber, el Auto del Juzgado Central de Instrucción n. ${ }^{\circ} 4$ de la Audiencia Nacional de fecha 18 de marzo de 2003, dictado en la querella criminal interpuesta por un grupo de ciudadanos contra el Presidente de Venezuela Hugo Chávez y otros altos cargos venezolanos, denunciando delitos de terrorismo tipificados en los artículos

${ }^{61}$ SÁnCHEZ PATrón, J. M.: «La relación entre la Corte Penal Internacional y las jurisdicciones nacionales: las dimensiones sustantiva y procesal del principio de complementariedad», Revista Jurídica de la Comunidad Valenciana, n. ${ }^{\circ} 10$, abril 2004, pp. 82-83.

62 Puede verse asimismo el Dictamen del Consejo de Estado (Comisión Permanente) de 3 de febrero de 2000, sobre el Proyecto de Acuerdo entre el Reino de España y las Naciones Unidas para la ejecución de sentencias dictadas por el Tribunal Penal Internacional para la ex Yugoslavia. 
571 a 580 del Código Penal español y de lesa humanidad recogidos en el artículo 7 del Estatuto de Roma derivados de la represión a los opositores políticos al régimen (supuestamente, entre otros mecanismos, a través de grupos paramilitares y otros grupos violentos afines a los dirigentes gubernamentales). En la parte dispositiva del Auto se acuerda "no admitir a trámite la querella interpuesta» (por la inmunidad de que goza el presidente venezolano en activo), añadiéndose a continuación que "una vez sea firme la presente resolución, remitase testimonio de todo lo actuado a la Fiscalía de la Corte Penal Internacional con sede en la Haya», de conformidad con lo dispuesto en los artículos 14 y 15 del Estatuto de Roma.

\section{ASPECTOS CONSTITUCIONALES REFERENTES AL CASTIGO DE LOS RESPONSABLES Y AL DESAGRAVIO DE LAS VÍCTIMAS}

\section{El régimen de las condenas privativas de libertad}

El último estadio de la persecución de las graves violaciones de derechos humanos tiene que ver con el castigo de los responsables. En esta fase ulterior se ha planteado una problemática constitucional nada desdeñable acerca del régimen de las condenas privativas de libertad aplicable a los responsables de graves atentados contra la dignidad. Así, desde la perspectiva transnacional, la posible contradicción entre el artículo 77 del Estatuto de la Corte Penal Internacional (que incluye dentro del catálogo de penas aplicables la de reclusión a perpetuidad, cuando lo justifiquen la extrema gravedad del crimen y las circunstancias personales del condenado) y el artículo 25.2 de la Constitución española (reeducación y reinserción social) es correctamente analizada y salvada en el citado Dictamen del Consejo de Estado español de 22 de julio de 1999, al analizar las diversas modulaciones que prevé el propio Estatuto de Roma (sobre todo el artículo 110, que prevé la reducción de las penas, cuya revisión podrá plantearse por ejemplo a los veinticinco años de prisión en caso de cadena perpetua) o que existen en otros países miembros de la Unión Europea (en los que la reclusión perpetua coexiste con el beneficio de la libertad condicional).

Al hilo de lo reseñado, conviene recordar que la pena de prisión en España tiene una duración máxima de veinte años como regla general, aunque excepcionalmente pueda prolongarse hasta treinta (artículo 36 del Código Penal de 1995, en su redacción dada por Ley Orgánica 15/2003), o incluso cuarenta años cuando el sujeto haya sido condenado por dos o más delitos y al menos dos de 
ellos estén castigados por Ley con pena de prisión superior a veinte años, o cuando el sujeto haya sido condenado por dos o más delitos de terrorismo y alguno de ellos está castigado por la Ley con pena de prisión superior a veinte años (artículo 76 del Código Penal, según asimismo modificación operada por Ley Orgánica 15/2003). El juego de la interpretación es muy amplio y debe cohonestar la vigencia de las diversas reglas hermenéuticas. Sin embargo, a fuerza de poner tanto el acento en la limitación o en la reducción de las penas como medida de reeducación y reinserción social, nos hemos visto confrontados a interpretaciones polémicas que venían generando desesperanza y desazón en la ciudadanía y en las víctimas y que, a la postre, no parecían sino requerir una reinterpretación más equitativa.

En este ambiente, la sentencia del Tribunal Supremo (Sala de lo Penal) $n .^{\circ}$ 197/2006, de 28 de febrero de 2006 (caso Parot) pone de manifiesto, precisamente en un supuesto referente a graves violaciones de derechos humanos (individuo condenado por múltiples atentados terroristas en España) que la problemática constitucional acerca del régimen de las condenas privativas de libertad sigue abierta, en concreto en lo atinente a la limitación temporal de varias penas impuestas a un mismo culpable cuando no sea posible el cumplimiento simultáneo de todas ellas, una limitación adoptada con soporte en controvertidas razones de política criminal que se solapan con determinado entendimiento de la inexistencia en España de cadena perpetua. Con estas premisas, se aborda ese régimen de limitación temporal de las penas a la luz del artículo 70 del Código penal de 1973, que era el aplicable al supuesto controvertido, razonando el Tribunal Supremo que el límite de treinta años no se convierte en una nueva pena, distinta de las sucesivamente impuestas al reo, ni por consiguiente, en otra resultante de todas las anteriores, sino que tal límite representa el máximo de cumplimiento del penado en un centro penitenciario; por ello el término a veces empleado, llamando a esta operación una «refundición de condenas», resulta inapropiado, de suerte que las varias penas se irán cumpliendo por el reo con los avatares que le correspondan, y con todos los beneficios a los que tenga derecho.

Según mi parecer, la mayoría del Tribunal Supremo (a la sentencia se une un voto particular discrepante) perfila su razonamiento jurídico de forma adecuada bajo la óptica de los principios de igualdad y de irretroactividad de lo desfavorable, con un soporte lógico y técnico jurídico aceptable desde la perspectiva de nuestro ordenamiento constitucional que, adicionalmente, parece acercarse más a la lógica y a la conciencia de lo justo imperante en la sociedad. En otras palabras, el criterio mayoritario me parece más comprometido con la defensa de los derechos humanos y con parámetros de militancia democrática y, por ende, re- 
fuerza más nuestro ordenamiento constitucional y su apertura a las normas internacionales sobre derechos humanos, mientras la postura minoritaria resulta marcadamente técnica o más aséptica y se acerca a cánones de una especie de politica criminal correcta; todo ello, obviamente, a reserva de los eventuales pronunciamientos ulteriores de la justicia constitucional y de la justicia europea sobre este asunto.

En estrecha conexión asimismo con el problema de fondo de la limitación temporal de las penas, más polémica desde el punto de vista jurídico se presentó la Sentencia de 8 de noviembre de 2006, de la Sección primera de la Sala de lo Penal de la Audiencia Nacional, dictada en el caso De Juana Chaos (Sumario 51/2005, rollo de Sala 82/2005, procedente del Juzgado Central de Instrucción n. ${ }^{\circ} 1$, por un delito de integración en organización terrorista y seis delitos de amenaza terrorista), siendo acusadores el Ministerio Fiscal en el ejercicio de la acción pública y la Asociación Víctimas del Terrorismo ejerciendo la acusación popular. La Audiencia falló la absolución en cuanto al delito de integración en organización terrorista en virtud del derecho fundamental a la legalidad penal en su vertiente de no condena dos veces por los mismos hechos, acogiendo en cambio la petición de condena por amenazas terroristas a doce años y siete meses de prisión por dos artículos publicados en el diario Gara en los que señalaba con nombres y apellidos a jueces y a funcionarios de prisiones.

El soporte argumental para llegar a esa conclusión condenatoria se asentaba en la concepción de la libertad de expresión como derecho limitado o no absoluto, para lo cual en la sentencia de la Audiencia Nacional se menciona explícitamente jurisprudencia constitucional y europea, a mi modo de ver en este caso de forma desacertada: en última instancia, da la impresión de haberse forzado extemporáneamente los resortes de nuestro ordenamiento jurídico para evitar la excarcelación del penado, llamando la atención que la Audiencia Nacional traiga a colación la sentencia constitucional sobre la Mesa Nacional de Herri Batasuna (STC 136/1999, de 20 de julio) en lo relativo a los límites a la libertad de expresión, en lugar del controvertido criterio (que a la sazón tuvo mayor peso) de la infracción del principio de proporcionalidad; del mismo modo, resulta llamativo que la Audiencia Nacional se remita a casos importantes del Tribunal Europeo sobre libertad de expresión para poner el acento en las restricciones, eludiendo la cita de algún supuesto en donde el Tribunal de Estrasburgo consideró asimismo desproporcionada la injerencia de los poderes públicos (en especial, el caso Castells contra España, de 23 de abril de 1992). Dicho sea de paso, la utilización, tanto en el caso de la Mesa de Herri Batasuna como en el caso Castells, del principio de proporcionalidad por el Tribunal Constitucional y por el Tribunal Europeo, 
respectivamente, tampoco deja de ser controvertida ${ }^{63}$ ni de suscitar un «efecto desaliento" ${ }^{64}$.

En todo caso, el carácter controvertido de la sentencia la Audiencia Nacional quedó corroborado por la rebaja de condena (de doce a tres años de prisión, facilitando con ello su excarcelación) decidida por el Tribunal Supremo mediante su sentencia n. ${ }^{\circ}$ 149/2007, de 26 de febrero de 2007 ${ }^{65}$ : mediante ésta, se otorgaba mayor peso a la libertad de expresión y se declaraba que no hubo delito de integración en banda armada ni delito de amenazas terroristas, sino amenazas no condicionales causadas a varios grupos de personas (artículos $169.2^{\circ}$ y $170.1 \mathrm{del}$ Código Penal) en concurso ideal con delito de enaltecimiento o justificación del

${ }^{63}$ En la STC 136/1999, de 20 de julio se afirma en principio de forma contundente que el terrorismo constituye una manifestación delictiva de especial gravedad, que pretende instaurar el terror en la sociedad y alterar el orden constitucional democrático, por lo que ha de admitirse que cualquier acto de apoyo al mismo comporta una lesión, al menos potencial, para bienes jurídicos individuales y colectivos de enorme entidad, a cuya defensa se dirige el tipo delictivo analizado. En coherencia con ello, se añade que no puede negarse en abstracto la posibilidad de que el Estado limite mediante el establecimiento de sanciones penales el ejercicio de los derechos fundamentales para garantizar bienes tan relevantes como la vida, la seguridad de las personas o la paz social que son puestos en peligro por la actividad terrorista $\left(\mathrm{FJ} 27^{\circ}\right)$; por tal motivo, no cabe concluir que la reacción penal resulta innecesaria y que las medidas no penales tendrían un grado de funcionalidad manifiestamente similar (FJ $28^{\circ}$ ). Sin embargo, luego se produce un salto argumental a través de una discutible interpretación del principio de proporcionalidad según el cual la norma que se ha aplicado a los recurrentes no guarda, por su severidad en sí y por el efecto que la misma comporta para el ejercicio de las libertades de expresión y de información, una razonable relación con el desvalor que entrañan las conductas sancionadas (FJ 29 ). Contra la STC 136/1996 presentó una demanda la Asociación de Victimas del Terrorismo contra España (demanda n. ${ }^{\circ}$ 54102/00) ante el Tribunal Europeo. Éste la declaró inadmisible mediante decisión de 29 de marzo de 2001, tras entender que "la asociación demandante y sus miembros pueden ciertamente pretender que se han visto afectados muy de cerca por las circunstancias que envuelven los hechos controvertidos, teniendo en cuenta, en particular, su calidad de víctimas, ellos mismos o miembros de sus familias, de las actividades de ETA. El Tribunal, por lo demás, es consciente de la gravedad de la situación a este respecto. Sin embargo, a la vista de lo que precede, el Tribunal no puede sino constatar que el procedimiento penal controvertido no se refiere a una denuncia sobre los derechos y obligaciones de carácter civil de la demandante ni sobre una acusación en materia penal dirigida contra ella en el sentido del artículo 6 del Convenio. De lo que se desprende que la demanda es incompatible ratione materiae con las disposiciones del Convenio en el sentido del artículo 35.3, debiendo ser rechazada en aplicación del artículo 35.4».

${ }^{64}$ Véase Cuerda RiezU, A.: «Proporcionalidad, efecto desaliento y algunos silencios en la Sentencia del Tribunal Constitucional 136/1999, que otorgó el amparo a los dirigentes de Herri Batasuna", en el colectivo La ciencia del Derecho penal ante el nuevo siglo. Libro homenaje al Profesor Doctor Don José Cerezo Mir, Madrid, Tecnos, 2002; así como De Domingo Pérez, T.: «La argumentación jurídica en el ámbito de los derechos fundamentales: en torno al denominado "chilling effect" o efecto desaliento", Revista de Estudios Políticos, n. ${ }^{\circ}$ 122, 2003.

${ }^{65}$ Recurso de casación n. ${ }^{\circ} 11281 / 2006$ P. 
terrorismo (artículo 578 del Código Penal). Llama la atención, sin embargo, el carácter estrictamente técnico del razonamiento del Tribunal Supremo, apoyándose en su propia jurisprudencia y omitiendo cita alguna de pronunciamientos del Tribunal Constitucional o del Tribunal Supremo ${ }^{66}$.

En fin, según se anticipó, que el caso De Juana Chaos está estrechamente relacionado con la cuestión de la limitación temporal de las penas privativas de libertad, queda patente de manera expresa en la propia sentencia de la Audiencia Nacional de 8 de noviembre de $2006^{67}$. Desafortunadamente, esta sentencia (y, a fortiori la STS de 26 de febrero de 2007) venía a confirmar la necesidad de la (re)interpretación de la limitación temporal de las penas efectuada en el caso Parot por un lado y, por otro lado, la pertinencia de una regulación explícita de las amenazas proferidas (con actitud desafiante y desprovista de todo arrepentimiento $\left.{ }^{68}\right)$ a los jueces por parte de los imputados incluso en el curso de los juicios orales, para satisfacer así el triple test impuesto por el Convenio Europeo de Derechos Humanos y por el Tribunal de Estrasburgo consistente en que las limitaciones estén previstas por la ley, persigan un fin legítimo y sean necesarias en una sociedad democrática (esto, en conexión con el principio de proporcionalidad). Y, por supuesto, más allá del supuesto concreto referente a De Juana (que ha rezumado privilegios escandalosos a la luz de la opinión pública mayoritaria, tanto por el «descontrolado» régimen de visitas en el hospital madrileño durante la huelga de hambre como por su «flexible» régimen especial de salidas en el hospital donostiarra — con una permisividad de la Administración penitenciaria que ha ignorado el efectivo control judicial del régimen atenuado de privación de libertad $\left.^{69}\right)$, lo que se pone de manifiesto es la necesidad de plantear

${ }^{66} \mathrm{La}$ excepción que confirma esta regla es el siguiente párrafo en el FJ $3^{\circ}$ : «No es lo mismo un delito de opinión que los de comisión de atentados con resultado de muerte u otros. Véase el auto de esta Sala de 23.5.2002 y particularmente la cita que se hace de la STC 199/1987».

${ }^{67}$ En cuyo FJ $1^{\circ}$.a) «el Tribunal no discute que el procesado estuviere alterado por los continuos retrasos en su excarcelación definitiva, pero si en efecto, tal y como ha manifestado lo que pretendia era luchar contra la campaña mediática que se habia iniciado contra su persona y poner en conocimiento de la opinión pública su situación, ninguna necesidad tenía de referirse a personas concretas con nombres y apellidos, ya que los artículos periodísticos no perderían ni un ápice de su fuerza narrativa y de la finalidad con aquellos pretendida por su autor si se hubieran suprimido tales referencias a jueces y funcionarios de prisiones concretos y determinados».

68 Tampoco es sencilla la regulación del estatuto de los terroristas arrepentidos: sobre esta problemática, puede leerse el artículo de HERNÁNDEZ VELASCO, I.: “¿Qué hacer con los terroristas arrepentidos?», diario El Mundo, jueves 7 de diciembre de 2006, p. 41: «El nombramiento de una ex miembro de las Brigadas Rojas para ocupar un cargo público desata el debate en Italia».

${ }^{69} \mathrm{El}$ artículo 100 (clasificación penitenciaria y principio de flexibilidad) del Real Decreto 190/1996, de 9 de febrero, por el que se aprueba el Reglamento Penitenciario dispone: «1. Además de 
un debate serio sobre la constitucionalidad del sistema de ejecución penal (partiendo del artículo 117.3 de la Constitución española) delimitando y acotando las competencias de la Administración penitenciaria y las de los Jueces de Vigilancia.

\section{El perdón de los responsables}

Abundando en esta fase final de exigencia de responsabilidad de quienes perpetren graves violaciones de derechos humanos, la controversia constitucional relativa al perdón de aquéllos pasa por recordar que la Constitución española impide aplicar el indulto a los supuestos en que se haya condenado por traición o por cualquier delito contra la seguridad del Estado al Presidente del Gobierno y a los demás miembros del Gobierno en el ejercicio de sus funciones (artículo 102.3). En conexión con ello, la Constitución española (artículo 62.i) prohíbe expresamente las leyes que autoricen indultos generales ${ }^{70}$. Es cierto que en España se cuenta con una Ley de indulto decimonónica (de 18 de junio de 1870, modificada por Ley 1/1988, de 14 de enero), que todavía necesita ser actualizada y, en la práctica, el Tribunal Constitucional español ha modulado la discrecionalidad del Gobierno en la concesión de indultos (obligando, como mínimo a motivar la denegación de tramitación de solicitud de indulto, por ejemplo, en la STC 163/2002 de 16 de septiembre), superando con ello la jurisprudencia del Tribunal Supremo en la materia. A esta línea evolutiva tampoco ha permanecido ajeno el Tribunal Europeo de Derechos Humanos (por todos, caso Mouisel contra Fran-

las separaciones señaladas en el artículo anterior, tras el ingreso los penados deberán ser clasificados en grados. Los grados serán nominados correlativamente, de manera que el primero se corresponda con un régimen en el que las medidas de control y seguridad serán más estrictas, el segundo con el régimen ordinario y el tercero con el régimen abierto. 2. No obstante, con el fin de hacer el sistema más flexible, el Equipo Técnico podrá proponer a la Junta de Tratamiento que, respecto de cada penado, se adopte un modelo de ejecución en el que puedan combinarse aspectos característicos de cada uno de los mencionados grados, siempre y cuando dicha medida se fundamente en un programa específico de tratamiento que de otra forma no pueda ser ejecutado. Esta medida excepcional necesitará de la ulterior aprobación del Juez de Vigilancia correspondiente, sin perjuicio de su inmediata ejecutividad».

70 Bajo tal ángulo, tuvo una indudable repercusión a la luz del precepto constitucional la concesión «en bloque» de más de mil indultos (1.443 Reales Decretos de Indulto) publicados en el BOE de 1 de diciembre de 2000, entre los que figuraba uno que produjo gran polémica, a saber, el indulto de un juez condenado por prevaricación por la Sala de lo Penal del Tribunal Supremo (sentencia de 15 de octubre de 1999): sobre este polémico indulto, puede leerse el trabajo de Aguado Renedo, C.: "Análisis (estrictamente jurídico) de un indulto conflictivo: el "caso Gómez de Liaño"”, Revista Española de Derecho Constitucional, n. ${ }^{\circ}$ 63, 2001. 
cia de 14 de noviembre de 2002, en donde sin reconocer obviamente el derecho subjetivo al indulto, sí se exige motivar adecuadamente la denegación de gracia en supuestos como los presos que se encuentren gravemente enfermos, pues en tal caso el Estado no estaría respetando los fines del sistema penal infligiendo un trato inhumano y degradante contrario al artículo 3 del Convenio Europeo de Derechos Humanos).

De todos modos, la cuestión referente al perdón de los responsables ha suscitado mayor interés en España con motivo de la actuación de la justicia española como justicia extraterritorial, puesto que el reiterado artículo 23 de la Ley Orgánica del Poder Judicial exige, para que pueda perseguirse en España este tipo de delitos «sin fronteras» por violaciones graves de los derechos humanos, que el delincuente no haya sido absuelto, indultado o penado en el extranjero. Esta fue, precisamente, una de las cuestiones espinosas con las que se enfrentó el juez titular del Juzgado Central de Instrucción n. ${ }^{\circ} 5$ de la Audiencia Nacional española cuando dictó el mencionado Auto de 28 de junio de 1996. En éste, me parece acertado el modo en que afronta el juez instructor la inaplicabilidad de la cosa juzgada o la ausencia total de virtualidad de las Leyes argentinas sobre perdón de los responsables. Y ello, como digo, desde la propia perspectiva del ordenamiento español, sin necesidad de acudir a la importante jurisprudencia internacional (sobre todo, de la Corte interamericana de derechos humanos) sobre la no aceptación de estas leyes claramente atentatorias contra la conciencia de la humanidad y la dignidad personal (por todos, el caso Barrios Altos - contra Perú- de 14 de marzo de 2001), con independencia del nombre que se dé a dichas leyes, incluso denominaciones casi eufemísticas como, pongamos por caso, la Ley uruguaya de caducidad de la acción punitiva del Estado (Ley 15.848). En la misma línea, un ejemplo paradigmático de adecuación a los cánones internacionales de lucha contra la impunidad en materia de graves violaciones de derechos humanos, en este caso a las orientaciones del sistema interamericano de derechos humanos, viene suministrado por la Sentencia de la Corte Suprema de Argentina de 14 de junio de 2005 declarando la nulidad de las leyes de impunidad y ratificando condena por crímenes contra la humanidad.

Como complemento de lo anterior, el perdón del ofendido, como causa de extinción de la responsabilidad criminal, que en España se prevé en el artículo 130 del Código Penal, sólo podrá ser otorgado cuando la Ley lo prevea, se conceda de forma expresa y antes de que se haya dictado sentencia. A mayor abundamiento, como problemática a caballo entre el castigo y el perdón de los responsables, debe subrayarse que el Código Penal español, cuando regula la prescripción de los delitos (artículo 131), establece explícitamente que «los delitos de lesa humanidad y de genocidio y los delitos contra las personas 
y bienes protegidos en caso de conflicto armado, no prescribirán en ningún caso" (apartado 4, según redacción introducida mediante Ley Orgánica 15/2003, de 25 de noviembre).

\section{La reparación de las víctimas}

Un último - pero importantístimo a la postre — aspecto constitucional en este escenario tiene que ver con la reparación de las víctimas de graves violaciones de derechos humanos, que trasciende lo estrictamente jurídico (no sólo la efectividad jurídica de las resoluciones judiciales en la materia, sino asimismo su valor ético como desagravio de las víctimas), para adentrarse en la función básica del juez como protector de los derechos humanos desde lo que podríamos denominar parámetros de militancia democrática, sensibilidad ética o compromiso ideoló$\mathrm{gico}^{71}$. En estas coordenadas, el derecho de los responsables de esas atrocidades a la seguridad jurídica está llamado a ceder (recuérdese la conciencia creciente de que los crímenes contra la humanidad no prescriben nunca) frente al superior y prevalente derecho a la verdad de las víctimas y sus familiares ${ }^{72}$. Evidentemente, la «verdad» judicial se halla expuesta en menor medida a riesgos de politización que las «comisiones de la verdad» $»^{73}$ (o denominaciones parecidas) creadas en al-

71 Véase García Belaunde, D.: «Los derechos humanos como ideología», Lima, Revista Derecho, n. ${ }^{\circ} 36$, diciembre 1992 , pp. 97 y ss.

72 En torno a esta problemática, léase EyMar AlOnso, C.: «Derecho y olvido. Algunas consideraciones en torno a la prescripción del delito", Revista Española de Derecho Militar, n. ${ }^{\circ} 77$, 2001, pp. 279-312.

73 Al respecto, ha observado MÉNDEZ, J. E.: «Derecho a la verdad frente a las graves violaciones a los derechos humanos», www.aprodeh.org.pe/sem_verdad/documentos/Juan_E_Mendez.doc, p. 15: «como método de averiguación de los hechos las comisiones de la verdad tienen una limitación importante, porque a pesar de los esfuerzos investigativos y de corroboración, tenderán a reflejar mucho más la visión de las víctimas o en todo caso dependerán, para una visión más equilibrada, de la cooperación de los represores, que rara vez se presta voluntariamente. Precisamente por no ser órganos jurisdiccionales, las comisiones de la verdad en general no cuentan con los instrumentos de investigación y de autoridad estatal para hacerse de pruebas compulsivamente, como sí lo hacen los tribunales de justicia. Además, todo proceso de búsqueda de la verdad fáctica es implícitamente falible; ni las comisiones de la verdad ni los tribunales están exentos de cometer errores. Pero como método de llegar a la verdad, no se ha encontrado hasta ahora forma más eficiente que la confrontación sistemática del procedimiento contencioso. Además, la verdad obtenida en juicio en que los acusados gozan de igualdad de armas para confrontar la prueba de cargo, ofrecer la propia e invocar causales de justificación de todo tipo tiene un poder persuasivo y una calidad especial que la hace innegable. Ese carácter de innegable de los hechos en disputa es al que debe aspirar el Estado que quiera cumplir de buena fe con su obligación de hacer respetar 
gunos países en donde se han producido graves violaciones de derechos huma$\operatorname{nos}^{74}$; y, por supuesto, comisiones parlamentarias «de la verdad» como la del 11-M en España suministran un ejemplo todavía más ostensible de esa politización ${ }^{75}$.

Desgraciadamente, el derecho a la verdad se ve ensombrecido en ocasiones al romperse el equilibrio entre el desagravio de la víctima y la garantía de los derechos fundamentales de los responsables de graves violaciones de los derechos humanos, a favor de esta segunda garantía y en perjuicio de aquel desagravio. De hecho, el juego de las garantías procesales ha llegado a configurarse como un escollo prácticamente insalvable en tal sentido, propiciando que se genere una solución material de presunción de inocencia en lugar de, respetando procedi-

y garantizar el ejercicio del derecho a la verdad». Este trabajo se encuentra publicado asimismo bajo el mismo título en el colectivo La aplicación de los tratados sobre derechos humanos por los tribunales locales, Buenos Aires, CELS, pp. 517-540.

${ }^{74}$ Es interesante acercarse a este mecanismo a través de la lectura del trabajo de ÚBEDA DE TORRES, A.: "Justicia transicional y comisiones de verdad: ‘avance o retroceso en el Derecho internacional contemporáneo?», Revista de Ciencias Jurídicas, San José de Costa Rica, n. ${ }^{\circ} 108$, septiembre-diciembre 2005, p. 17: con la expresión «justicia transicional» se «trata de aunar, de reunir bajo un mismo concepto y en el mismo grupo a proceso $s$ de índole completamente diversa, ya se trate del cambio de regímenes dictatoriales hacia la instauración o la consolidación de la democracia, el cambio de una situación de conflicto armado hacia un proceso progresivo de pacificación, el cambio desde una sociedad dominada por la violencia generalizada a una sociedad respetuosa de los derechos humanos, o dos o más de estas circunstancias a la vez. En definitiva, con la idea de justicia transicional se quiere hacer referencia tanto a situación de transición simple, como a las de transición doble».

${ }^{75}$ La Comisión de investigación parlamentaria del 11-M aprobó en junio de 2005 el dictamen final de los trabajos (el dictamen final fue aprobado por todos los grupos parlamentarios excepto el PP, que en cambio sí respaldó algunas propuestas para mejorar la atención a las víctimas del terrorismo o para mejorar la seguridad del Estado). Las conclusiones y recomendaciones de la comisión se estructuran en tres partes. La primera analiza el fenómeno terrorista internacional de raíz islamista, su amenaza sobre España antes del 11-M y la reacción del Estado ante esa amenaza. La segunda parte del dictamen se centra en la forma en que las instituciones civiles y políticas respondieron a los atentados y se examina la conducta del Gobierno español, presidido entonces por José M. ${ }^{a}$ Aznar. Finalmente, la tercera parte del Dictamen de la Comisión expone las recomendaciones de futuro sobre medidas a adoptar para que un 11-M nunca pueda volver a repetirse, que se refieren a la atención de las víctimas y mejora de la seguridad del Estado «frente al terrorismo islamista» mediante la cooperación policial y judicial, potenciación de recursos y una mayor coordinación institucional. Además, propone al Gobierno que impulse reformas legales para combatir el control de las fuentes de financiación del terrorismo, la inmigración ilegal, regular la figura del confidente y mejorar el control de explosivos. Asimismo, también se aboga por un paquete de medidas para mejorar la relación con la religión musulmana y promover una política exterior de seguridad. Por último, la comisión de investigación recomienda a los partidos políticos la realización de un Pacto contra el Terrorismo Internacional, abierto a todas las fuerzas políticas democráticas, para evitar que pueda volver a repetirse un hecho tan trágico como el del 11-M. 
mentalmente esas garantías, retrotraer actuaciones para volver a valorar las pruebas que determinen o no la antijuridicidad y la culpabilidad del imputado (por ejemplo, caso Barberà, Messegué y Jabardo contra España, del Tribunal Europeo de Derechos Humanos). Pero, afortunadamente, la comunidad internacional se sigue mostrando sensible al derecho a la verdad, como lo demuestra la Convención internacional para la protección de todas las personas contra las desapariciones forzadas adoptada en junio de 2006 (de manera coetánea a la elaboración de ese proyecto de Convención de Naciones Unidas, en el ámbito de la OEA su Asamblea General aprobó en su cuarta sesión plenaria, celebrada el 6 de junio de 2006, una Resolución sobre el derecho a la verdad).

A la luz de estas recientes tendencias internacionales, el ordenamiento constitucional puede verse perfeccionado al abordar de manera amplia los perfiles de este novedoso derecho a la verdad (que puede considerarse tanto una prolongación del derecho a la tutela judicial efectiva, como una manifestación de la libertad de información — derecho a ser informado sobre informaciones que están en posesión del Estado), pudiendo considerarse su satisfacción como uno de los fines inmediatos y específicos del proceso penal que, sin perjuicio de la aplicación de las sanciones preceptivas a los autores de las graves violaciones de los derechos humanos, comporta un indisociable derecho de los familiares de las víctimas y de la sociedad en su conjunto a la efectiva averiguación de lo ocurrido. Correlativamente, ese derecho implica una más cualificada obligación positiva de los Estados para poner en marcha todos los mecanismos a su alcance susceptibles de contribuir al esclarecimiento de lo realmente acontecido. El debate científico en este ámbito es espinoso pero, cuando menos, los perfiles reseñados han de tenerse presentes con un enfoque prospectivo.

\section{REFLEXIONES FINALES}

\section{La lucha contra la impunidad como exigencia axiológica de un orden constitucional internacionalizado}

Llegados a este punto, merece la pena efectuar unas consideraciones conclusivas. En efecto, las situaciones de graves violaciones contra los derechos humanos analizadas en el presente trabajo, tanto las estrictamente internacionales como las nacionales, son susceptibles de alterar la gobernabilidad democrática y la convivencia pacífica de la sociedad estatal que las padece directamente y, por extensión, de la comunidad internacional, por lo que se impone una lucha determinante contra la impunidad respecto de ese tipo de violaciones. 
Para ello, obviamente, es preciso que el combate frente a esas actitudes antidemocráticas se efectúe con medios democráticos.

En cuanto a los remedios internos, cabe destacar, por referencia a lucha contra la violencia terrorista, las medidas que en España se han adoptado para frenarla desde las exigencias democráticas, por más que se perfilen como "políticamente poco correctas»: a título de ejemplo, la vigente Ley de partidos políticos (Ley Orgánica 6/2002) permitió ilegalizar judicialmente ante el Tribunal Supremo a las asociaciones consideradas como brazo político del terrorismo, ilegalización que ha venido avalada por el Tribunal Constitucional mediante varias sentencias importantes (STC 48/2003 de 12 de marzo, y SSTC 5 y 6/2004 ambas de 16 de enero $)^{76}$.

Las mencionadas sentencias constitucionales han tenido como efecto adicional que los partidos ilegalizados no hayan podido consecuentemente participar en los procesos electorales en España, un resultado avalado por otros pronunciamientos del Tribunal Constitucional, como la STC 85/2003, de 8 de mayo ${ }^{77}$. Lo anterior, empero, ha venido matizado por el episodio que se ha ce-

76 Sobre el particular, léase Vírgala ForURIA, E.: «Los partidos políticos ilícitos tras la LO 6/2002", Teoría y Realidad Constitucional, n. ${ }^{\circ} 10-11,2003$, p. 245: en este trabajo se subraya que, pese a la existencia de una jurisprudencia constitucional que ha reconducido la aplicación de los artículos 24 y 25 de la Constitución a los procedimientos judiciales y al Derecho sancionador, «nada impide su aplicación en una organización que por mandato constitucional ha de ser democrática». Acúdase asimismo a la obra de Tajadura Tejada, J.: Partidos Políticos y Constitución. Un estudio de la LO 6/2002, de 27 de junio, de Partidos Políticos y de la STC 48/2003, de 12 de marzo, Madrid, Civitas, 2004: el citado autor argumenta y defiende con solidez que la Ley Orgánica 6/2000 tiene fundamento constitucional; que para ello no le hace falta asumir un modelo de democracia militante; que no vulnera el principio non bis in idem; que tampoco vulnera los derechos fundamentales a la libertad ideológica, participación, expresión e información, ni siquiera a través de la controvertida inclusión del apoyo tácito al terrorismo en el apartado a) del artículo 9.3 de la Ley; que de igual modo ésta tampoco vulnera las exigencias de previsibilidad ni desconoce el principio de proporcionalidad; que no es una Ley de carácter singular o de "caso único»; que no infringe el principio de irretroactividad; que no menoscaba el derecho de asociación por el hecho de limitar a los españoles la facultad de crear partidos políticos; que el carácter constitutivo del régimen de inscripción registral no contradice el artículo 22.3 de la Carta Magna. Por lo demás, en España se han dictado otras Leyes con tal finalidad, como la que tiende a bloquear la financiación a partidos que apoyen el terrorismo y a proveer medidas de protección de cargos públicos amenazados por los terroristas (Ley Orgánica 1/2003, de 10 de marzo, para la garantía de la democracia en los Ayuntamientos y la seguridad de los concejales). Otras prolongaciones interesantes de este problema se han suscitado con motivo de sentencias constitucionales posteriores, como la STC 68/2005, de 31 de marzo, con respecto a los criterios para determinar el carácter defraudatorio de agrupaciones de electores que comportan una continuidad de un partido político previamente ilegalizado.

77 Una crítica sobre esta cuestión ha sido formulada por SALAZAR BENÍTEZ, O.: «La dudosa constitucionalidad de las limitaciones del derecho de sufragio pasivo previstas por la L.O. 6/2002, 
rrado en el ámbito nacional con motivo de las elecciones autonómicas y municipales de 27 de mayo de 2007 por medio de dos SSTC 110 y 112/2007, de 10 de mayo de 2007, mediante la que se deniegan los amparos solicitados y se rechazan, de un lado, la estrategia de un partido ilegalizado («Abertzale Sozialistak«) de concurrir fraudulentamente a los comicios a través de agrupaciones de electores y, de otro lado, las candidaturas igualmente fraudulentas de un partido no ilegalizado ( Acción Nacionalista Vasca») ${ }^{78}$.

Si el fondo del asunto referente la confirmación de la anulación de todas las listas del partido ilegal «Abertzale Sozialistak» no ha suscitado una especial discusión, sí han generado polémica la circunstancia de que en el segundo supuesto el Gobierno (a través de la Abogacía del Estado) y la Fiscalía sólo impugnaran 133 candidaturas de los tres centenares de ellas presentadas por «Acción Nacionalista Vasca», lo que en definitiva ha conllevado una especie de «ilegalización parcial» de este último partido ${ }^{79}$. Este episodio de la impugnación y consiguiente anulación de una parte de las listas de "Acción Nacionalista Vasca» ha puesto de relieve la ausencia de consenso en materia antiterrorista entre el partido gubernamental y el primer partido de la oposición, así como una politiza-

de partidos políticos. Comentario a las SSTS de 3 de mayo y a la STC 85/2003, de 8 de mayo", Revista de Estudios Politicos, n. ${ }^{\circ}$ 122, octubre-diciembre 2003, pp. 139-140: el citado autor mantiene, desde luego, uno de los criterios susceptibles de ser sostenidos en clave jurídica; pero me parece excesivamente comedido o políticamente correcto; por ello, me parece una opción jurídica igualmente relevante y, sobre todo, más comprometida en términos de militancia democrática, la sostenida —en su análisis sobre el proceso de elaboración de la Ley de partidos políticos- por BLANCO VALDÉS, R.: «La nueva ley de partidos. A propósito de la ilegalización de Batasuna», Claves de razón práctica, $\mathrm{n} .{ }^{\circ}$ 124, 2002. Esa misma militancia democrática, que finalmente no es sino defender el núcleo axiológico de la propia Constitución (la dignidad), se desprende del trabajo de VÍRgala ForURIA, E.: «La dimensión externa del principio de constitucionalidad de los partidos políticos en el ordenamiento jurídico español", Teoría y Realidad Constitucional, n. ${ }^{\circ} 12 / 13,2 .{ }^{\circ}$ semestre 2003-1 ${ }^{\circ}$ semestre 2004, p. 249.

${ }^{78}$ La primera de las sentencias constitucionales de 10 de mayo de 2007 (STC 110/2007) deniega el recurso de amparo n. ${ }^{\circ} 4107 / 2007$ y otros 22 acumulados, confirmando la Sentencia del Tribunal Supremo de 5 de mayo de 2007 (Sala Especial del artículo 61 LOPJ) mediante la que se anulaban todas las agrupaciones de electores de "Abertzale Sozialistak». La segunda de las sentencias del Tribunal Constitucional de 10 de mayo de 2007 (STC 112/2007) deniega el recurso de amparo n. ${ }^{\circ} 4215 / 2007$, confirmando los Autos de 4 y 5 de mayo de 2007 dictados por el Tribunal Supremo (Sala Especial del artículo $61 \mathrm{LOPJ}$ ) en la pieza separada abierta dentro del proceso de ejecución n. ${ }^{\circ} 1 / 2003$ dimanante de las actuaciones acumuladas n. ${ }^{\circ}$ 6/2002 y 7/2002, sobre ilegalización de partidos políticos.

79 Una crítica a esa estrategia impugnatoria y a ese efecto de «ilegalización parcial» ha sido efectuada por Vidal Prado, C.: "Un camino mal escogido», Diario La Razón, 10 de mayo de 2007, p. 13. 
ción de la materia que ha proyectado su sombra sobre la Sentencia constitucional de 10 de mayo de 2007 denegatoria del recurso de amparo formulado por dicho partido vasco: algo más que anecdótico parece ser, en efecto, que el mismo día 11 de mayo de 2007 en que se hizo pública esa sentencia constitucional, el Alto Tribunal hubo de publicar un auto de aclaración mediante el que se suprimía un controvertido párrafo incluido "por error» en aquélla ${ }^{80}$.

Volviendo a la inicial STC 48/2003, como se dijo, fue recurrida por el Gobierno Vasco ante el Tribunal Europeo de Derechos Humanos, siendo inadmitida la demanda ratione personae mediante Decisión de 3 de febrero de 2004. Las SSTC 5 y 6/2004 todavía no han sido resueltas en Estrasburgo, en donde la Corte Europea a buen seguro dictará sentencia sobre el fondo, que a mi juicio tiene muchas posibilidades de ser desestimatoria a tenor de la jurisprudencia más reciente de dicha Corte, en la que se da por bueno el recurso al margen de apreciación estatal y a la cláusula "pas de liberté pour les ennemis de la liberté» del artículo 17 del Convenio Europeo de Derechos Humanos. Me refiero especialmente al caso Partido de la Prosperidad y otros contra Turquía de 31 de julio de $2001^{81}$. Sin embargo, en el caso Kavakçi contra Turquía, de 5 de abril de 2007, el Tribunal Europeo se ha mostrado más cauto a la hora de limitar los de-

${ }^{80}$ El párrafo en cuestión indicaba textualmente que «la disolución y hasta la suspensión de dicho partido en razón de esa sola circunstancia hubiera planteado quizás el problema de si cabría entenderla manifiestamente desproporcionada, aun cuando no pueda descartarse que, en unión de otras, pudiera llevar en su momento a esa última consecuencia. En cualquier caso, es evidente que el hecho de que esa solución radical se estimase hoy impracticable por quienes pudieran instarla o decidirla, no implica que no fuera obligado arbitrar otras, toda vez que la actividad defraudatoria intentada habría producido, de perfeccionarse, consecuencias de muy difícil reparación, pues la eventual disolución posterior del partido ahora legal no afectaría al mandato representativo de aquellos de sus candidatos que resultaran elegidos». El auto de aclaración del Tribunal precisa que ese párrafo "no forma parte de la sentencia» y que ha figurado en ella "por error».

${ }_{81}$ Más tarde, la sentencia dictada por la Gran Sala en fecha 13 de febrero de 2003 en el caso Partido de la Prosperidad, tras el reexamen del asunto, confirmó por unanimidad de los diecisiete magistrados componentes del colegio que no había habido vulneración del artículo 11 del Convenio. Comparto esa militancia democrática del Tribunal Europeo, por más que obviamente haya que extremar el examen de este tipo de restricciones, como ha advertido GARCÍA ROCA, J.: «La problemática disolución del Partido de la Prosperidad ante el TEDH: Estado constitucional y control de las actuaciones de partidos fundamentalistas", Revista Española de Derecho Constitucional, n. $^{\circ}$ 65, mayo-agosto 2002, p. 313: la lucha contra el terrorismo «no es por sí misma una patente de corso que justifique una medida desproporcionada, en ausencia de mayores razones y pruebas, dentro de lo que debe ser un control jurídico estricto del asociacionismo político». Véase asimismo GARCÍA ROCA, J.: "Abuso de derechos fundamentales y defensa de la democracia (artículo 17 CEDH)", en el colectivo La Europa de los derechos. El convenio Europeo de Derechos Humanos (coord. J. García Roca y P. Santolaya Machetti), Madrid, Centro de Estudios Políticos y Constitucionales, 2005. 
rechos políticos a la luz del artículo 3 del Protocolo n. ${ }^{\circ} 1$ adicional al Convenio de Roma de 1950, decretando la violación de dicha disposición convencional como consecuencia de la decisión de la Asamblea Nacional turca de no permitir la adquisición de la condición de parlamentaria de una electa del «Partido de la Virtud" (Fazilet Partisi) por prestar juramento o promesa de acatar el ordenamiento constitucional turco con el velo islámico ${ }^{82}$.

Con el mismo espíritu debería acometerse, sin menoscabo de los derechos de las víctimas del terrorismo, el desafío actual en España por acabar con el terrorismo a través del diálogo (truncado al parecer con el atentado del 30 de diciembre de 2006 en el aeropuerto de Barajas) con terroristas e integrantes de su brazo político, entendido dicho desafío como un ejercicio por parte del Gobierno español de su función de dirección de la política interior y exterior. En la línea de la política interior, merece la pena ubicar el Auto del Tribunal Supremo (Sala de lo Penal) de fecha 13 de noviembre de 2006 dictado en el recurso n. $^{\circ}$ 20389/2006, mediante el que se acordaba inadmitir la querella formulada, ejercitando la acción popular, por el Sindicato de Funcionarios Públicos «Manos Limpias» por presuntos delitos de prevaricación, desobediencia y quebrantamiento de medidas cautelares, contra el Presidente del Gobierno, los miembros del Consejo de Ministros, el Secretario General de Organización del Partido Socialista Obrero Español y el Coordinador de la ejecutiva PSE-EE (la querella se fundaba en que los querellados habrían abierto una vía de diálogo y mantenido reuniones con partidos afines a ETA ilegalizados por el Tribunal Supremo y que figurarían en la lista de organizaciones terroristas establecidas por la Unión Europea): en el $\mathrm{FJ} 3^{\circ}$ del auto se afirma que «vendría a ser un fraude constitucional que alguien pretendiese, mediante el ejercicio de la acción penal y la puesta en marcha de un proceso de la misma naturaleza, corregir la dirección de la politica interior o exterior que el art. 97 CE encomienda al Gobierno democráticamente legitimado».

La negociación política, pese a todo, no debiera confundirse con el margen de negociación jurídica susceptible de ser utilizada en controversias sobre graves violaciones de derechos humanos. ¿A qué me refiero? Pues a que los contactos políticos o la negociación política abordados en el mencionado Auto del Tribunal Supremo de 13 de noviembre de 2006 no son equiparables al acuerdo alcanzado por la representante del Gobierno venezolano y la representación procesal de algunos etarras ante la Comisión Interamericana de Derechos Humanos (informe de admisibilidad N. $37 / 06$ aprobado el 8 de noviembre de 2006 en el marco de su

${ }^{82}$ Cfr. sentencia del Tribunal Europeo de Derechos Humanos de fecha 29 de junio de 2004, dictado en el caso Leyla Sahin contra Turquia. 
$124^{\circ}$ periodo de sesiones): si ese acuerdo (consistente en indemnizar a dos etarras supuestamente entregados de manera ilegal por Venezuela a la Justicia española en 2002, y en otorgar la nacionalidad venezolana a otros cuatro etarras) resulta escandaloso desde un punto de vista político, a mi modo de ver se revelaba ante todo inadmisible desde una perspectiva jurídica. Si en el ámbito mercantil suele decirse que es preferible el peor acuerdo al mejor pleito, semejante concepción no es en absoluto trasladable en cualquier caso al campo de los derechos humanos pues, como es sabido, la conciliación o el arreglo pacífico o amistoso que deben facilitar la Comisión Interamericana o el propio Tribunal Europeo de Derechos Humanos no implica aceptar todo acuerdo alcanzado por las partes litigantes. Lo cual significa que, en ocasiones, no procederá admitir acuerdo alguno, dado que deberá imponerse una solución «ejemplar» guiada por el respeto de los derechos humanos que comportará una condena mediante sentencia sobre el fondo del asunto; $y$, en otras ocasiones, procederá «rebajar» el acuerdo alcanzado por las partes, para que se guarde un equilibrio entre la supuesta violación provocada y la compensación otorgada a las presuntas víctimas, ya que esa compensación habrá de ser «equitativa» y no desmesurada e insultante para la dignidad de otras personas afectadas. La lectura jurídica que postulo debe, por lo demás, enmarcarse en lo resuelto por la Corte Interamericana de Derechos Humanos en su Opinión Consultiva OC-19/05, de 28 de noviembre de 2005, en la que se pronunció sobre el alcance del control de legalidad en el ejercicio de las atribuciones de la Comisión Interamericana.

El supuesto mencionado me permite enlazar con la función de dirección política exterior, respecto de la cual vale la pena mencionar la Resolución del Parlamento Europeo de fecha 25 de octubre de 2006 dando soporte al «proceso de paz» para acabar con la lacra del terrorismo en España. Ese apoyo internacional, como antes indicaba, no debe concebirse de manera espuria como mera politización del problema interno, sino como un nuevo impulso para seguir mejorando la situación nacional de respeto de los derechos humanos y que ésta siga siendo objeto de atención o fiscalización internacional, incorporándose mecanismos de restablecimiento del derecho a la verdad a favor de las víctimas del terrorismo y, en paralelo, observándose cánones preventivos como, pongamos por caso, la intervención del Comité Europeo contra la Tortura del Consejo de Europa.

La utilización de esos cánones preventivos permitirá evitar gravísimas situaciones como la de los prisioneros de Guantánamo en manos de Estados Unidos, que ha dado lugar a resoluciones importantes como la Decisión de la Comisión Interamericana de Derechos Humanos de 12 de marzo de 2002 y a comentarios del Comité Internacional de la Cruz Roja respecto del estatuto legal 
de los detenidos en Guantánamo (en esos comentarios se rechazaba el calificativo de "combatientes ilegales» — «unlawful combatants»— atribuido por Estados Unidos a los prisioneros de guerra de Guantánamo, y se esgrimía que no hay zonas intermedias en conflictos armados que dejen a nadie en manos enemigas fuera de la ley y, por tanto, al margen de toda protección) ${ }^{83}$. Posteriormente, secundando esta orientación, el Tribunal Supremo de Estados Unidos dictó una decisión histórica en junio de 2004 sobre Guantánamo (caso Rasul contra Bush) que implicaba que los órganos jurisdiccionales de primera instancia se reputaban competentes para decidir sobre el alcance de los derechos civiles de los detenidos en Guantánamo. Ahora bien, los avances mencionados no han evitado -ni previsiblemente evitarán- nuevos pronunciamientos del Tribunal Supremo, como la reciente sentencia de 29 de junio de 2006 dictada en el caso Hamdam contra Rumsfeld declarando ilegales los tribunales de excepción de Guantánamo.

Siguiendo con los reproches a Guantánamo, las críticas conexas surgidas en el ámbito europeo suscitaron asimismo en España una justificada reacción negativa frente a la ya citada sentencia de la Sala de lo Penal (Sección 4. ${ }^{a}$ ) de la Audiencia Nacional n. ${ }^{\circ}$ 43/2005 de 4 de octubre (caso del "talibán español») en lo concerniente al no cómputo como período de prisión provisional del tiempo de detención en la base de Guantánamo. Sin embargo, la crítica más acerba la formuló el propio Tribunal Supremo al casar dicha sentencia mediante la también mencionada Sentencia n. 829 de 22 de junio de 2006 (dictada en el recurso de casación núm. 1188/2005 P), en cuyo fallo no es que se discrepe del no cómputo del tiempo transcurrido en Guantánamo, sino que se llega a absolver al condenado haciendo prevalecer la presunción de inocencia tras analizar «todas aquellas cuestiones que tienen su origen en la estancia en la base americana de Guantánamo», que califica de «limbo jurídico» y de ejemplo de «Derecho penal del enemigo ${ }^{84}$.

En este contexto, tanto en el plano internacional como en el ámbito nacional debe efectuarse el preceptivo esfuerzo por los actores competentes para cumplimentar las obligaciones positivas que propicien la consecución de la gobernabilidad democrática y la lucha contra la impunidad sin alterar las relaciones pacíficas a escala mundial. Justamente, uno de los aspectos que pretende resaltar el presente trabajo es que la catalogación de las violaciones graves de

${ }^{83}$ Esa visión crítica en SHELTON, D.: «The Legal Status of the Detainees at Guantanamo: Innovate Elements in the Decision of the Interamerican Comission of HumanRights of 12 march 2002", Human Rights Law Journal, vol. 23, n. . 1-4, pp. 13-14.

84 Vid. Zaffaroni, E. R.: El Enemigo en el Derecho Penal, Madrid, Dykinson, 2007. 
derechos humanos da pie para emprender una acción de sinergia nacional e internacional tendente a facilitar la gobernabilidad democrática y la convivencia pacífica a nivel mundial. Con tal enfoque, las medidas normativas y las jurisdiccionales (con el soporte de la acción de las fuerzas policiales y, eventualmente, militares) han de ir de la mano. Las aportaciones jurisprudenciales y, en especial, la retroalimentación de los jueces internos e internacionales, son susceptibles de una menor politización y, por ende, de menores reticencias soberanas. Así, los pronunciamientos de jueces internos ejerciendo competencia universal deben verse como una fase positiva de evolución de la defensa internacional de los derechos humanos y de relatividad de las fronteras como potenciales obstáculos a la responsabilidad por graves atentados contra la dignidad humana. Estos pronunciamientos, por mucha repercusión política que proyecten, permiten fortalecer la posición del individuo en su ordenamiento constitucional y, por ende, asimismo en Derecho internacional, así como las correlativas obligaciones positivas de los Estados.

En este marco positivo se inscriben las ya reseñadas STC 237/2005, de 26 de septiembre y sentencia n..$^{\circ}$ 16/2005, de 19 de abril, de la Audiencia Nacional sobre competencia universal de los tribunales españoles. En todo caso, si son numerosas las desdichas sufridas en todos los continentes, la última guerra de Irak ha potenciado el movimiento internacional a favor del ejercicio de la competencia universal en materia de graves violaciones de derechos humanos y la consiguiente lucha contra la impunidad. Esta es la lectura que cabe efectuar de la sentencia dictada por unanimidad el 5 de diciembre de 2006 por la Sala Penal del Tribunal Supremo (caso Couso) mediante la que se revoca la previa decisión de la Audiencia Nacional (auto de 10 de marzo de 2006) de archivar la investigación sobre la muerte en Irak el 8 de abril de 2003 del cámara de Telecinco al ser atacado el hotel en donde se encontraba por un tanque norteamericano ${ }^{85}$.

\section{El equilibrio entre una respuesta constitucional comprometida internacionalmente y una reacción constitucional proporcionada: nuevos perfiles de los derechos constitucionales en juego}

Las decisiones de justicia nacional extraterritorial se sitúan en un marco de equilibrio entre una respuesta constitucional comprometida internacionalmen-

${ }^{85} \mathrm{La}$ Comisión de Asuntos Exteriores del Congreso de los Diputados aprobó el 18 de abril de 2007 una proposición no de ley presentada por el grupo parlamentario de la muerte de José Couso en Irak. 
te y una reacción constitucional proporcionada. Dichas decisiones tal vez constituyan la única compensación y alivio que les quede a las víctimas, pronunciamientos judiciales que condenen, que responsabilicen, que se manifiesten contra la impunidad, todo ello siquiera - como mínimo, pero ya es algo- en recuerdo de las víctimas y sus familiares, que tendrán un soporte jurídico, pero también moral, para que no se niegue la barbarie sufrida y, en definitiva, aquéllos no se vean sumidos en el olvido. Lo fundamental de la experiencia positiva en el contexto nacional y en el internacional en materia de responsabilidad por graves violaciones de derechos humanos radica en que esa experiencia sea conocida por la opinión pública internacional y difundida de tal modo que se genere una verdadera cultura democrática internacional. Lo que, en cambio, suscita mayor controversia, es el valor pedagógico de potenciales pronunciamientos judiciales que deriven de procesos de restablecimiento de una cierta versión "científica» de la historia (STC 43/2004, de 23 de febrero), a menos que realmente se trate de defender los derechos humanos frente a tesis revisionistas y negacionistas de barbaries contrastadas históricamente (por ejemplo, decisión de inadmisibilidad del Tribunal Europeo de Derechos Humanos de 24 de junio de 2003, dictada en el caso Garaudy contra Francia, demanda n. ${ }^{\circ}$ 65831/01; o caso Violeta Friedman, STC 214/1991, de 11 de noviembre).

Claro que, el ejercicio de las obligaciones positivas por parte de los Estados en esa creciente internacionalización del Derecho constitucional e internacionalización del Derecho internacional, especialmente cuando entra en juego la satisfacción del derecho a la verdad, no siempre encuentra un eco unánime en las fuerzas políticas internas ni en la opinión pública (nacional o internacional). Y ello tanto si se trata de una ley de proyección interna (por ejemplo, el proyecto español de "Ley de la memoria histórica», cuyo título exacto es el de Ley por la que se reconocen y amplían derechos y se establecen medidas en favor de quienes padecieron persecución o violencia durante la Guerra Civil y la Dictadura ${ }^{86}$ - en conexión con dicho proyecto, léase la STC 123/2004, de 13 de julio-), como si se trata de Estados afectados por leyes extraterritoriales (verbigracia, la proposición de Ley francesa que sanciona la negación del genocidio armenio, adoptada en primera lectura por la Asamblea Nacional el 12 de octubre de 2006, por 106 votos a favor y 19 en contra —en conexión ella, puede leerse el Auto del Tribunal de Primera Instancia, Sala Primera, de 17 de diciembre de 2003, sobre supuesta responsabilidad extracontractual de la Unión Europea por haber reconocido a la República de Turquía el estatuto de Estado candidato a la adhesión a la Unión siendo así

${ }^{86}$ Proyecto de Ley 121/000099, BOCG (Congreso de los Diputados), VIII Legislatura, Serie A: Proyectos de Ley, 8 de septiembre de 2006, Núm. 99-1. 
que dicho Estado se había negado a reconocer el genocidio perpetrado en 1915 contra los armenios que residían en Turquía-) ${ }^{87}$.

Para concluir: la integración europea y la mundialización, como retos del Derecho constitucional que vienen realzados precisamente por la necesidad de luchar en el orden constitucional y en el orden internacional contra las graves violaciones de los derechos humanos, dotan de un fuerte dinamismo a las nociones y conceptos básicos de nuestra disciplina y, por ello mismo, imponen al estudioso un esfuerzo renovado de adaptación y conceptuación. Las lagunas normativas derivadas de los problemas conceptuales van acompañadas irremediablemente por una labor jurisprudencial nada desdeñable, lo cual aconseja un enfoque metodológico en el que convergen las tendencias prevalentes del civil law y las orientaciones imperantes en el common law, en una combinación más o menos equilibrada de apego a la ley y de recurso a la jurisprudencia, respectivamente. Así lo he intentado dejar plasmado en este trabajo, dando cuenta de los avances normativos y de los progresos jurisprudenciales en la materia.

Por lo demás, el reiterado reto de la internacionalización del Derecho constitucional o la constitucionalización del Derecho internacional he pretendido ilustrarlo con un tema de indudable actualidad y precisado de investigación, empezando por la propia aportación sobre qué deba entenderse por grave violación de derechos humanos, qué ventajas y resultados útiles prevalecen sobre los inconvenientes y controversias suscitadas por mecanismos como la euroorden o el ejercicio de la jurisdicción universal, qué enseñanzas positivas - frente a las menos favorables - cabe extraer de proyectos legislativos de carácter intemporal o de alcance extraterritorial para perseguir graves atentados contra la dignidad humana, qué nuevos perfiles (a título, cuando menos, prospectivo) adquieren en nuestro ordenamiento constitucional derechos fundamentales como la tutela judicial efectiva o la información como cauces de reparación y desagravio de las víctimas de graves violaciones, o qué equilibrios cabe encontrar entre esos derechos de las víctimas y los correlativos derechos que asisten a los verdugos sin que

${ }^{87}$ De interés resulta, para una completa visión sobre las fuentes de la «memoria histórica» no sólo en España, sino en otros países, la consulta del Boletín de Documentación del Centro de Estudios Políticos y Constitucionales, n. ${ }^{\circ}$ 27, septiembre-diciembre 2006, Dossier: Memoria Histórica. El Proceso de Justicia Transicional en Alemania, Argentina, Chile, España, Portugal y Sudáfrica. En particular, para el caso español, el capítulo IV «España: una transición consensuada» (pp. 136211), en el que aparecen las normas aprobadas durante la transición (1976-1978), la legislación de la democracia (1979-2006), la legislación de las Comunidades Autónomas, iniciativas legislativas y actos de control de las Cortes Generales, jurisprudencia del Tribunal Constitucional, reparaciones, archivos y memorias, y direcciones web. Para el caso francés, puede consultarse La Documentation française, monográfico sobre «Loi et mémoire», octubre 2006. 
medie una quiebra de los principios básicos en los que se asienta el orden constitucional y el orden internacional... sin perder de vista que esos nuevos perfiles comportan una profundización en el desarrollo del núcleo axiológico de nuestra Norma Suprema (la dignidad humana) y de la apertura más favorable a los instrumentos internacionales en materia de derechos humanos. Y esa profundización, en última instancia, no constituye o no debe constituir un aséptico estudio con selección de objeto, contenido, método y retos propios del Derecho constitucional sino, además y sobre todo, una apuesta de militancia democrática a favor del ordenamiento constitucional.

Title

Constitutional Order and Serious Violations of Human Rights

\section{Summary}

I. The Constitutional law before the serious violations of human rights: 1. The object of study: a great challenge for our discipline. 2. Current importance of the constitutional questions where the serious violations of the human rights are involved. II. Personal approach: classification of the serious violations of human rights. III. Constitutional reflections on the investigation of the serious violations of human rights: 1 . Constitutional Spanish framework and measures taken at the European level. 2. International criminal assistance and new instruments: special attention to the «EuroOrder». 3. The investigation from Spain of violations of human rights having a universal transcendency. IV. Constitutional profiles of the prosecution of the serious violations of human rights: 1 . The opening of the constitutional order to the international criminal jurisdiction. 2. Constitutional aspects of the extraterritorial competence of the Spanish jurisdictional organs. 3. Action of synergy and feedback between both the constitutional and the international legal orders. V. Constitutional aspects related to the punishment of the individuals in charge and to the memory of the victims: 1 . The regime of the condemnations imposed to those having seriously violated human rights. 2 . The pardon of the individuals in charge. 3. The compensation of the victims. VI. Final reflections: 1. The fight against the impunity as an essential and axiological requirement of an internationalized constitutional order. 2 . The balance between a strong international commitment and a proportionate constitutional reaction: new profiles of the constitutional rights in play. 


\title{
Resumen
}

El presente trabajo afronta un desafío fundamental para el Derecho constitucional, a saber, el análisis del marco constitucional español referente a la responsabilidad por graves violaciones de derechos humanos. En este sentido, en primer lugar, el trabajo introduce una posición original sobre los tipos de graves violaciones de derechos humanos, las cuales están relacionadas con los más horrendos atentados contra la dignidad humana y contra las bases del sistema democrático, teniendo una proyección tanto en el plano constitucional como en el universal. A continuación, en la parte central del trabajo se examina sucesivamente siguiendo un esquema lógico las diversas etapas de lucha contra la impunidad de los individuos responsables por graves violaciones de derechos humanos: la investigación, el enjuiciamiento y la condena por esos actos criminales, sin olvidar la reparación de las víctimas. En todas esas etapas se toma en consideración el marco legal nacional (terrorismo y crímenes contra la humanidad contemplados en el Código penal) y el supranacional (crímenes universales previstos en el Estatuto de la Corte Penal Internacional y en otros tratados internacionales de Derecho internacional penal y humanitario, así como en la Unión Europea); y se tiene en cuenta asimismo el progreso conocido en el ámbito de la jurisprudencia nacional (jurisdicción universal) y de la jurisprudencia internacional (la puesta en funcionamiento de la Corte Penal Internacional y de los Tribunales Penales para la ex Yugoslavia y para Ruanda). Finalmente, se incluyen unas conclusiones sobre la necesidad de forjar un compromiso en la lucha contra la impunidad universal (tanto por parte de la ciudadanía como por parte de los poderes públicos, especialmente con «voluntad jurisdiccional»), así como sobre los nuevos perfiles o desarrollos de los derechos fundamentales en juego (sobre todo, el derecho a la tutela judicial efectiva, el derecho a la información y, en conexión con ellos, el novedoso «derecho a la verdad»).

\begin{abstract}
The present work tackles a fundamental challenge for the Constitutional law, namely, the analysis of the Spanish constitutional framework concerning the responsibility for serious violations of human rights. In this respect, first, the work introduces an original approach on the types of serious violations of human rights, which are related to the most horrible attempts on the human dignity and on the bases of the democratic system, having a projection both in the constitutional and in the universal field. Later, in the central part of the work, the author examines successively — following a logical scheme — the diverse
\end{abstract}


steps of the fight against the impunity of the responsible individuals for serious violations of human rights: the investigation, the prosecution and the condemnation for these criminal acts, without forgetting the compensation of the victims. In all these stages the work takes in consideration the national legal framework (terrorism and crimes against the humanity contemplated in the Criminal Code) together with the supranational one (universal crimes foreseen in the Statute of the International Criminal Court and in other international agreements on criminal and humanitarian International Law, as well as in the European Union); it also takes in consideration the progress known in the field both of the national jurisprudence (universal jurisdiction) and of the international jurisprudence (the functioning of the International Criminal Court and of the International Criminal Courts for the former Yugoslavia and for Rwanda). Finally, a few conclusions are included on the need to forge a commitment in the fight against the universal impunity (both on the part of the citizenship and on the part of the public authorities, specially with «jurisdictional will»), as well as on the new profiles or developments of the fundamental rights in play (especially, the right to the due process of law, the freedom of information and, in connection with them, the new «right to the truth»).

\section{Palabras clave}

Internacionalización del Derecho constitucional, Constitucionalización del Derecho internacional, justicia universal, legislación universal, crímenes universales, universalización de la dignidad humana, derecho a la verdad, espacio europeo de justicia, memoria y reparación de las víctimas

\section{Key words}

Internationalization of the Constitutional law, Constitutionalization of the International Law, universal justice, universal legislation, universal crimes, universalization of the human dignity, right to the truth, European area of justice, memory and compensation of the victims 